Columbia Law School

Scholarship Archive

2008

\title{
Learning from Difference: The New Architecture of Experimentalist Governance in the EU
}

\author{
Charles F. Sabel \\ Columbia Law School, csabel@law.columbia.edu \\ Jonathan Zeitlin \\ jzeitlin@facstaff.wisc.edu
}

Follow this and additional works at: https://scholarship.law.columbia.edu/faculty_scholarship

Part of the Comparative and Foreign Law Commons, and the European Law Commons

\section{Recommended Citation}

Charles F. Sabel \& Jonathan Zeitlin, Learning from Difference: The New Architecture of Experimentalist Governance in the EU, 14 EUR. L. J. 271 (2008).

Available at: https://scholarship.law.columbia.edu/faculty_scholarship/1526

This Article is brought to you for free and open access by the Faculty Publications at Scholarship Archive. It has been accepted for inclusion in Faculty Scholarship by an authorized administrator of Scholarship Archive. For more information, please contact scholarshiparchive@law.columbia.edu. 


\title{
Learning from Difference: The New Architecture of Experimentalist Governance in the $\mathbf{E U}$
}

\author{
Charles F. Sabel* and Jonathan Zeitlin**
}

\begin{abstract}
This article argues that current widespread characterisations of EU governance as multi-level and networked overlook the emergent architecture of the EU's public rule making. In this architecture, framework goals (such as full employment, social inclusion, 'good water status', a unified energy grid) and measures for gauging their achievement are established by joint action of the Member States and EU institutions. Lower-level units (such as national ministries or regulatory authorities and the actors with whom they collaborate) are given the freedom to advance these ends as they see fit. But in return for this autonomy, they must report regularly on their performance and participate in a peer review in which their results are compared with those pursuing other means to the same general ends. Finally, the framework goals, performance measures, and decision-making procedures themselves are periodically revised by the actors, including new participants whose views come to be seen as indispensable to full and fair deliberation. Although this architecture cannot be read off from either Treaty provisions or textbook accounts of the formal competences of EU institutions, the article traces its emergence and diffusion across a wide range of policy domains, including telecommunications, energy, drug authorisation, occupational health and safety, employment promotion, social inclusion, pensions, health care, environmental protection, food safety, maritime safety, financial services, competition policy, state aid, anti-discrimination policy and fundamental rights.
\end{abstract}

\footnotetext{
* Maurice T. Moore Professor of Law, Columbia University.

** Professor of Sociology, Public Affairs, Political Science, and History, University of Wisconsin-Madison; Director of the European Union Center of Excellence and the Center for World Affairs and the Global Economy (WAGE). For insightful comments on earlier drafts of this article, we are grateful to the members of the University of Wisconsin-Madison/Columbia Law School project on 'EU Governance: Towards a New Architecture?', to participants in conferences, workshops, and seminars organised by the EU 6th Framework Research Programme's CONNEX Network of Excellence on European Governance (Roskilde University), NEWGOV (New Modes of Governance) Project (University College, London), REFGOV (Reflexive Governance in the Public Interest) Project (Catholic University of Louvain), and TRANSLEARN (Transnational Learning through Local Experimentation) Project (Helsinki School of Economics); the ARENA Centre for European Studies (University of Oslo), the European Policy Research Unit (University of Manchester), the University of Pennsylvania, the Society for the Advancement of Economics (SASE), and the University of Wisconsin-Madison; as well as to Maurizio Ferrera, Jürgen Feick, Jan Zielonka, and an anonymous reviewer for the EUROGOV working papers series.
} 


\section{Introduction}

Wrestling with massive rapid expansion, buffeted by economic globalisation and demographic change, provoked by a bumbling effort to normalise its constitutional status, the EU is today in crisis, and will likely remain so for several years to come. The outcome of that crisis is unforeseeable, but any outcome short of a radical uprooting of administrative, judicial, and professional dispositions that have been decades in the making is likely to leave intact the novel pattern of rule making characteristic of governance in the EU. Paradoxically, it is precisely the distance from the world of parties, parliaments, and referenda that contributes to suspicion about the legitimacy of the EU which also protects some of its core institutions from political turbulence. Total disaster aside, what was true of EU governance yesterday is likely to be true tomorrow and the day after. This article is directed to analysis of the distinctive and surprisingly effective innovations that have emerged in EU governance in the frank hope if not expectation that a clear appreciation of these can usefully inform the next round of efforts to render the institutions of European decision making comprehensible and democratically accountable.

Looking then beneath and beyond the turbulence of the moment, but without disregarding the possibility of catastrophic outcomes, here is what we and other observers see: the EU is creating a single market while constructing a framework within which the Member States can protect public health and safety in ways that grow out of their own traditions and allow them to pursue their own best judgments for innovative advance. Similarly, it is encouraging the Member States to reconfigure their systems of social protection, and obligating them to learn from one another how best to retain their distinctive forms of solidarity in a radically new context. These steps in the direction of 'Social Europe' are all the more remarkable because they occur even as the Member States open markets for the provision of social services and accommodate the increased portability of claims to social welfare benefits. ${ }^{1}$

In a more analytic vein, it is agreed among the many who now take the EU to be a functioning novel polity without a state that its regulatory successes are possible because decision making is at least in part deliberative: actors' initial preferences are transformed through discussion by the force of the better argument. Deliberation in turn is said to depend on the socialisation of the deliberators (civil servants, scientific experts, representatives of interest groups) into epistemic communities, via their participation in 'comitological' committees: committees of experts and Member State representatives that advise the European Commission on new regulation and review its eventual regulatory proposals. ${ }^{2}$ The process of socialisation and the consensus that it generates is further said to be largely informal, in the sense that it was neither directly anticipated by, nor much less can it be deduced from, the directives and other legal instruments establishing various regulatory decision-making

\footnotetext{
1 M. Ferrera, The Boundaries of Welfare: European Integration and the New Spatial Politics of Social Protection (Oxford University Press, 2005).

${ }^{2}$ C. Joerges and J. Neyer, 'Transforming Strategic Interaction into Deliberative Problem-Solving: European Comitology in the Foodstuffs Sector', (1997) 4 European Journal of Public Policy 609; C. Joerges and E. Vos (eds), EU Committees: Social Regulation, Law and Politics (Hart, 1999); J. Neyer, 'Explaining the Unexpected: Efficiency and Effectiveness in European Decision-Making', (2004) 11 Journal of European Public Policy 19.
} 
processes. ${ }^{3}$ In the eyes of some it may also be 'informal' in the additional and suspect sense of establishing extra-legal workarounds that overcome institutional blockages in the EU's constitutional design. ${ }^{4}$

In the same analytic vein, this system of decision making is called 'multi-level' because it connects national administrations with each other and the EU without establishing a hierarchy between them: the decisions of 'lower'-level entities can influence the choice of ends and means at 'superior' levels. This multi-level concertation is used to overcome the political blockages to EU action that arise when actors at various levels make disjointed use of their veto powers. In solving this coordination problem, multi-level concertation is said to blur the distinction between centralised and decentralised decision making by networking various types of decision makers. ${ }^{5}$

Finally, this networked deliberative decision making is widely seen as a departure from the norms of representative democracy by which laws are legitimate only if they can exhibit a pedigree extending from a sovereign people assembled in the electorate through a legislative act as eventually adjusted by administrative elaboration. Deliberation, especially informal deliberation, among technical elites rather than decision making by majority vote of elected representatives naturally looks suspicious from this point of view. Whether the EU's deliberative decision making can accredit itself as legitimate by the emergent standards of some alternative deliberative democracy remains a question even for those who strongly suspect that it will turn out to be so.

In this essay, we will argue that useful though it is, this list of distinctive features of European governance crucially overlooks the underlying architecture of public rule making in the EU: the fundamental design for law making, and the way this design transforms the distinct elements of EU governance by connecting them into a novel whole. Although this decision-making architecture can neither be mapped from the topmost directives and Treaty provisions nor read out from any textbook account of the formal competences of EU institutions, it regularly and decisively shapes EU governance. In this decision-making design, framework goals (such as full employment, social inclusion, 'good water status', a unified energy grid) and measures for gauging their achievement are established by joint action of the Member States and EU institutions. Lower-level units (such as national ministries or regulatory authorities and the actors with whom they collaborate) are given the freedom to advance these ends as they see fit. Subsidiarity in this architecture implies that in writing framework rules the lower-level units should be given sufficient autonomy in implementing the rules to be

3 T. Christiansen and S. Piattoni (eds), Informal Governance in the European Union (Manchester University Press, 2000); B. Eberlein and E. Grande, 'Beyond Delegation: Transnational Regulatory Regimes and the EU Regulatory State', (2005) 12 Journal of European Public Policy 89.

${ }^{4}$ A. Héritier, Policy-making and Diversity in Europe: Escaping Deadlock (Cambridge University Press, 1999).

5 R. Dehousse, 'Regulation by Networks in the European Community: The Role of European Agencies', (1997) 4 Journal of European Public Policy 246; B. Kohler-Koch and R. Eising (eds), The Transformation of Governance in the European Union (Routledge, 1999); B. Kohler-Koch (ed), Linking EU and National Governance (Oxford University Press, 2003); E. Chiti, 'Decentralisation and Integration into the Community Administrations: A New Perspective on European Agencies', (2004) 10 European Law Journal 402; D. Geradin and P. Pettit, The Development of Agencies at EU and National Levels: Conceptual Analysis and Proposals for Reform, Jean Monnet Working Paper 01/04 (NYU School of Law, 2004); M. Egeberg (ed), Multilevel Union Administration: The Transformation of Executive Politics in Europe (Palgrave Macmillan, 2006); H.C.H. Hofman and A.H. Türk (eds), EU Administrative Governance (Edward Elgar, 2006). 
able to propose changes to them. ${ }^{6}$ But in return for this autonomy, they must report regularly on their performance, especially as measured by the agreed indicators, and participate in a peer review in which their results are compared with those pursuing other means to the same general ends. Finally, the framework goals, metrics, and procedures themselves are periodically revised by the actors who initially established them, augmented by such new participants whose views come to be seen as indispensable to full and fair deliberation.

It follows from this account that the concept of experimentalist governance should be understood in functional rather than structural or institutional terms. This means that the four key elements just listed should be understood as a set of necessary functions which can be performed through a variety of possible institutional arrangements. Put another way, there is in such an experimentalist architecture no one-to-one mapping of governance functions to specific institutional mechanisms or policy instruments, and vice versa. A single function, such as monitoring and review of implementation experience, can be performed through a variety of institutional devices, operating singly and/or in combination with one another. Conversely, a single institutional mechanism, such as a formal peer review exercise, can perform a number of distinct governance functions, such as assessing the comparative effectiveness of different national and subnational implementation approaches, opening up opportunities for civil society actors to hold governments accountable at national and EU levels, identifying areas where new forms of national or transnational capacity building are required, and/or contributing to the redefinition of common policy objectives.

With this qualification, and variously called fora, networked agencies, councils of regulators, open methods of coordination (OMCs), or more generally processes, we find the pattern of decision making just described in the regulation of telecommunications, energy, drug authorisation, environmental protection, occupational health and safety $(\mathrm{OH} \& \mathrm{~S})$, food safety, maritime safety, rail safety, data privacy, financial services, employment promotion, social inclusion, and pension reform, among many other areas. Similar arrangements have been recently inaugurated in other key areas such as health care, anti-discrimination policy, competition policy and state aid.

It is these processes of framework making and revision, we will see, that give precise definition to the deliberation, informalism, and multi-level decision making characteristic of the EU. Consider first deliberation. In conventional views of deliberative decision making, the goal is consensus and reflective equilibrium. In the EU by contrast, deliberative decision making is driven at least as much by the discussion and elaboration of difference. Indeed, consensus is regarded as provisional, a necessary condition for taking decisions that have to be confronted now, but certainly not the final word of discussion nor even a reflective equilibrium.

Take next informalism. The mutability of institutions and the lack in some cases of formal sanctions create the general impression of informal governance. But we will see that whatever the informal attributes of the governance system as a whole, those institutions whose explicit purpose is to expose and clarify difference so as to destabilise

\footnotetext{
${ }^{6}$ For an interpretation of subsidiarity in the EU along these lines, see G. de Búrca, Reappraising Subsidiarity's Significance after Amsterdam, Harvard Jean Monnet Working Paper 7/99 (Harvard Law School, 1999); G. de Búrca, 'Legal Principles as an Instrument of Differentiation? The Principles of Proportionality and Subsidiarity', in B. de Witte, D. Hanf and E. Vos (eds), The Many Faces of Differentiation in EU Law (Intersentia, 2001).
} 
and disentrench settled approaches and solutions are typically highly formalised. Indeed, it is only a slight exaggeration to say that it is the search for ever better ways of meeting this objective which explains the continuous institutional revision that creates the impression of informalism. At a minimum, the assertion of unbridled informalism is hard to square either with the formalisation of procedural requirements in key EU directives, let alone with the emergence of a body of EU administrative law directed to ensuring respect for certain formalities concerning access to, conduct of, and dissemination of deliberation without which the new architecture could not function effectively.

Finally, this architectural perspective complements and corrects the notion that multi-level governance is primarily concerned with overcoming political blockages through vertical concertation. Concertation is certainly a politically useful effect of multi-level governance. But such governance also reflects the division of labour inherent in a recursive conception of rule making. Even though EU officials and Member States collaborate in formulating frameworks and evaluating them, it is the distinctive role of the EU level to promulgate authoritative frameworks and oversee their enforcement, while it is the distinctive role of the Member States and subnational bodies to adapt these frameworks to their own circumstances and to report on their experience. The most successful of these arrangements combine the advantages of decentralised local experimentation with those of centralised coordination, and so blur the distinction between forms of governance often held to have incompatible virtues.

This profusion of common deliberative techniques not only prompts revision of partial descriptions of EU governance, but also challenges application to the EU of more settled, theoretically rooted views about the form and possibility of good governance current in liberal political economy, political science and jurisprudence. One such idea, derived from standard liberal views of the polity and the economy, is that market making (negative integration) should be governed by unambiguous, nearly self-enforcing rules too clear to be gamed; market correction (positive integration) by independent regulatory authorities acting under carefully delegated mandates; and social solidarity by political compromise. ${ }^{7}$ We will see, on the contrary, that regulation in all three realms increasingly takes the novel form of contestable rules to be understood as rebuttable guides to action even when they are also taken as enforceable sovereign commands.

By the same token, these developments challenge the related assumption that deliberative processes produce at most a monitory, 'soft' complement to 'hard' state-made law: non-binding guidelines, 'naming and shaming' by listing poor performers at the

\footnotetext{
${ }^{7}$ See, for example, G. Majone, Dilemmas of European Integration: The Ambiguities \& Pitfalls of Integration by Stealth (Oxford University Press, 2005). This profusion of common deliberative techniques also challenges empirical typologies of EU policy making such as that of Wallace and Wallace, which associates distinctive 'policy modes' (the 'traditional Community Method', an 'EU regulatory mode', an 'EU distributional mode', 'policy coordination', and 'intensive transgovernmentalism') with the functional and political characteristics of different policy domains. In the latest edition of their influential textbook, Wallace and Wallace themselves acknowledge both that 'it is becoming much harder to identify the contours of a single coherent EU regulatory mode' because of the proliferation of new governance arrangements, and that their ideal-typical categories increasingly 'overlap and spill into each other' in practice: see H. Wallace, W. Wallace and M. Pollack (eds). Policy-making in the European Union (Oxford University Press, 5th edn, 2005), at 82 and 487.
} 
bottom of league tables, and the like. ${ }^{8}$ In this view, deliberation can at most be a handmaiden to the tough political bargaining that produces real law. But we will see that in some cases, the new architecture routinely results either in revisions of EU directives, regulations, and administrative decisions, or in the elaboration of revisable standards mandated by law and the enunciation of new principles which may eventually be given binding force. In others, the changes may influence only the behaviour of national administrations with no immediate impact on the legal framework of the EU itself. For every decision-making process that produces outcomes apparently without legal sanctions, moreover, there is as a rough rule of thumb another in the same general domain where non-compliance can have draconian consequences. Often these take the form of what we will call a destabilisation regime: a reversion to traditional (and today unworkable) forms of law or rule making, or some other condition equally beyond the actors' control and therefore extremely alarming to them. The presence or absence of sanctions is, we will see, an incidental feature of particular processes of framework making and revision, not a fundamental attribute of the architecture as a whole.

A third revision of conventional interpretations concerns the rule of law. In standard liberal accounts, the rule of law depends on a clear distinction between the state, which may act only insofar as it is explicitly authorised to do so, and individuals, who may do whatever is not explicitly prohibited. In this view, the freedom of individuals is tied to limits on state power, and the limits are only effective when catalogued in detailed specifications of what is permissible to the authorities. Against this backdrop, the mutability of EU governance institutions looks not just like politically expedient informalism, but like a threat to the liberty of the moderns. But we will see that recursive framework making and revision is prompting the emergence of new forms of dynamic accountability and peer review which discipline the state and protect the rights of citizens without freezing the institutions of decision making. Arguably, these dynamic mechanisms provide effective ways of addressing longstanding accountability and rule-of-law deficits within the nation-state itself.

We call this new form of governance directly deliberative polyarchy (DDP). It is deliberative because it uses argument to disentrench settled practices and open for reconsideration the definitions of group, institutional, and even national interest associated with them. It is directly deliberative because it uses the concrete experience of actors' differing reactions to current problems to generate novel possibilities for consideration rather than buffering decision-makers in Madisonian fashion from experience of the world the better to elicit their principled, disinterested response to abstractly posed problems. It is polyarchic because it is a system in which the local units learn from, discipline, and set goals for each other. For this reason, it is especially well-suited to heterogeneous settings such as the EU, where the local units face similar problems, and can learn much from their separate efforts to solve them, even though particular solutions will rarely be generalisable in any straightforward way. In this sense, deliberative polyarchy is a machine for learning from diversity, thereby transforming an obstacle to closer integration into an asset for achieving it. Because of the way it systematically provokes doubt about its assumptions and practices, while unrelentingly treating its solutions as provisional and corrigible, DDP can be thought of as a form of

\footnotetext{
${ }^{8}$ Soft law has been more formally defined as 'rules of conduct which in principle have no legally binding force, but which nevertheless may have practical effects': see F. Snyder, 'Soft Law and Institutional Practice in the European Community', in S. Martin (ed), The Construction of Europe (Kluwer Academic Publishers, 1994), at 198.
} 
experimentalist governance in the pragmatist sense, and we will use the two terms interchangeably. ${ }^{9}$

The final conventional view that these developments challenge is that deliberation involving experts is tantamount to a supranational or transgovernmental conspiracy against democracy. But the dynamic accountability of EU governance has a potentially democratising destabilisation effect on domestic politics, and through them, in return, on the EU itself. ${ }^{10}$ The requirement that each national administration justify its choice of rules publicly, in the light of comparable choices by the others, allows traditional political actors, new ones emerging from civil society, and coalitions among these to contest official proposals against the backdrop of much richer information about the range of arguably feasible choices, and better understanding of the argument about their merits, than traditionally available in domestic debate. Whether or not the potential participants avail themselves of the possibilities thus created, and whether, if they do, the result is more fully democratic decision making (on any of the many dimensions on which this could be counted) are of course of matters of domestic institutional and political context. But to the extent this potential is realised, the linkage of domestic and supranational rule making in the EU does indeed create a democratising destabilisation effect. More generally, the widespread institution of peer review, experts criticising and responding to criticism by experts in public, undercuts the very notion of incontrovertible technocratic authority, and a fortiori the version of technocracy associated with the European Commission's monopoly on legislative initiative as informed and corrected by expert comitological scrutiny. Of course, as we shall have reason to insist repeatedly, in undermining technocracy through democratising destabilisation, the new architecture does not automatically produce democratic outcomes. It means rather that the new forms of decision making promote forms of accountability that are consistent with some aspects of democracy, though not necessarily furthering representative democracy in any traditional way.

The body of this essay documents and explores the operation of DDP in its various institutional forms across the full range of EU governance. Parts II and III establish the deep similarity of architectural outcomes in diverse domains of decision making. Thus we will show in Part II that fora and processes re-regulating privatised networked infrastructure, administrative agencies protecting public health and safety, as well as OMCs in employment and social protection, all exhibit key features of DDP. Part III looks at recent extensions of this new architecture. The first three concern regulatory rulemaking: in response to catastrophe (food and maritime safety); prudential regulation in advance of failure (financial services); rationalisation of centralised regulation (competition policy, state aid). The fourth extension, however, is from rules to rights: we will see that application and meaning of rights against, for example, discrimination on grounds of race, gender, or disability, is coming to rely on the same experimentalist mechanisms of direct and polyarchic deliberation that are enlisted in the elaboration and revision of regulatory rules.

\footnotetext{
${ }^{9}$ For earlier presentations of DDP and its application to the EU, see J. Cohen and C.F. Sabel, 'Directlydeliberative Polyarchy', (1997) 3 European Law Journal 313; O. Gerstenberg and C.F. Sabel, 'Directly Deliberative Polyarchy: An Institutional Ideal for Europe?', in C. Joerges and R. Dehousse (eds), Good Governance in Europe's Integrated Market (Oxford University Press, 2002); J. Cohen and C.F. Sabel, 'Sovereignty and Solidarity: EU and US', in J. Zeitlin and D.M. Trubek (eds), Governing Work and Welfare in a New Economy: European and American Experiments (Oxford University Press, 2003).

${ }^{10}$ The notion of a democratising destabilisation effect builds on arguments presented in C.F. Sabel and W.J. Simon, 'Destabilization Rights: How Public Law Litigation Succeeds', (2004) 11 Harvard Law Review 1015.
} 
For purposes of exposition, we initially portray these governance arrangements as more static than they are, leaving in the background many of the steps by which they assumed their present form, and referring only in passing if at all to the ways they are currently changing in response to the logic of self-adjustment which has become their animating principle. Part IV, in contrast, examines the theory and practice underpinning the distinctive dynamism of the new governance arrangements. It analyses the limits of principal-agent governance at the root of traditional state-made law, and shows how peer review can provide accountability under conditions of volatility where principal-agent relations characteristically break down. To illustrate this dynamic accountability in action, we complement the sectoral cases analysed previously by examining the elaboration and successive reforms of mechanisms for implementing the Water Framework Directive, and analogous modifications of the Environmental Impact Assessment Directive. Part V continues this discussion of accountability and democracy by looking empirically at the democratising destabilisation effects of DDP, with attention to a particularly unlikely case: the mutual transformation of EU institutions and their counterparts in the incomparably less powerful accession countries through the experimentalist process of enlargement.

Part VI concludes by arguing against viewing EU developments as exceptional. The EU, we will argue, has leapfrogged the USA in some key regulatory areas such as environmental protection and food and drug safety, developing experimentalist forms of rulemaking that had been introduced in the USA during the 1980s, but whose elaboration was blocked by idiosyncracies of the latter's electoral and political system. Finally, the EU's experimentalist methods of reconciling market integration and social ordering arguably anticipate the trajectory of the world trade regime as defined by the co-development of the World Trade Organisation (WTO) on the one side and the Sanitary and Phytosanitary (SPS) and Technical Barriers to Trade (TBT) Agreements on the other. So far from being aberrant, EU governance, understood as a whole rather than an assemblage of unusual parts, may be a forerunner of new forms of governance especially suited to the temper of our times at both national and global levels.

\section{Convergence on the Experimentalist Architecture: Three Routes}

Over the last decade, the EU has experienced the institutional equivalent of a Cambrian explosion of life forms: in what is by historical let alone evolutionary timescales an astonishingly short period, there has been a proliferation of related experimentalist 'body plans' across disparate policy domains. And just as the Cambrian explosion depended on prior genetic novelties, ${ }^{11}$ so too the profusion of new EU governance institutions in the 1990s builds on earlier innovations in the tools for constructing organisations. Of these, the most important was the comitological system of expert committees established in earlier decades to advise and supervise the European Commission's rulemaking.

Originally established by the Member States to ensure that the European Commission's elaboration of rules respected political compromises, comitological committees in short order moved from policing the outcome of rulemaking to technical collaboration with the rulemakers. Soon they became as much the artificers of European

11 D.H. Erwin and E.H. Davidson, 'The Last Common Bilaterian Ancestor' (2002) 129 Development 3021. 
Commission proposals as arbiters of their acceptability. ${ }^{12}$ By the late 1990 s, these collegia were synonymous in academic analysis with public-regarding deliberation by technical elites, and had proliferated working and advisory groups - all of these connected by a thicket of horizontal and vertical links. ${ }^{13}$ In the Cambrian explosion of institutional innovation that followed, comitology has been transformed from a stage in a para-legislative process focused on the European Commission to a building block of networked deliberation - by diverse groups of experts concerned with concrete problems and responding to the interventions of a concerned public - found at nearly every stage in framework making and revision.

The many variants of recursive or experimentalist architecture that built on and gave structure to this comitological deliberation neither emerged all at once nor in one central place within the EU's regulatory system. Given the growing recognition of the need to learn from diversity in order to harmonise, coordinate, and revise regulatory rules without imposing an unworkable uniformity, the new architecture took shape roughly between the mid-1980s and 2000, ie between the Single European Act and the Lisbon Summit. For purposes of exposition, and with no pretension to taxonomic comprehensiveness or precision, we can say that the architecture was elaborated more or less independently in three domains: re-regulation of privatised network infrastructure, public health and safety, and social solidarity. ${ }^{14}$

The re-regulation of privatised network infrastructure concerned sectors such as electricity, gas and telecommunications. The key step here was the creation of independent national regulatory authorities (NRAs), or reinforcement of the autonomy of existing ones, on condition that these authorities consult more widely with each other and the European Commission. These consultations among groups or councils of regulators take place through regular 'fora', as part of 'processes' in which implementation experience is reviewed with the end in view of correcting the regulatory framework.

The second domain - public health and safety-concerned regulation of, for example, drug authorisation, $\mathrm{OH} \& \mathrm{~S}$, environmental protection, food safety, maritime, rail, and aviation safety. Here the key step was the creation of new administrative agencies apparently inspired by US models but soon taking on a novel networked form. The most powerful of these formally perform an advisory function to the European Commission, but in fact possess quasi-regulatory authority insofar as their advice can be contravened only in extraordinary circumstances. Others are charged only with supplying technical information. But formal differences aside, both are becoming

${ }^{12}$ As a recent analysis of the role of comitological committees and expert groups in the EU policy-making process observes: 'It happens that groups/committees change hats (authority) almost at a moment's notice in a truly fascinating way. When they do, they may look the same but under a different name, and the participants may even be the same... In the implementation phase, a comitology committee often has a duplicate, an expert group with more or less the same crew as the committee, and in some cases a comitology committee can switch hats quickly, taking on the guise of an expert group during a meeting, if difficult issues arise which need more informal discussions': T. Larsson and J. Trondal, 'Agenda Setting in the European Commission: How the European Commission Structure and Influence the EU Agenda', in Hofman and Türk, op cit $\mathrm{n} 5$ supra, at 29-30.

${ }^{13}$ T. Christiansen and E. Kirchner (eds), Committee Governance in the European Union (Manchester University Press, 2000); Joerges and Vos, op cit $\mathrm{n} 2$ supra; M.P.C.M. van Schendelen (ed), EU Committees as Influential Policymakers (Ashgate, 1998).

${ }^{14}$ A fourth route, which we do not examine in this article, is the growth of networked operational cooperation among national authorities in the field of Justice and Home Affairs: see S. Lavenex and W. Wallace, 'Justice and Home Affairs', in Wallace et al, op cit n 7 supra; J. Monar, 'Justice and Home Affairs', (2005) 43 Journal of Common Market Studies (annual review issue) 131. 
animating centres of similar networks for pooling experience under the current regulations and learning about possible alternatives. ${ }^{15}$

In the third domain - social solidarity - the key innovation was the OMC, in which representatives of the Member States in consultation with the Commission set broad 'non-binding' goals and metrics, to be implemented through national action plans or strategies, and periodically revised following peer review of implementation experience.

From roughly the turn of the millennium onwards, as we will see in Part III, the new architecture became available not only as a response to catastrophic breakdowns in regulatory capacity (food safety, maritime safety/pollution) or the threat of these (financial market supervision), but also as a means for unblocking rule making in domains that had become stalemated by struggles between proponents of (traditional) centralisation and (traditional) decentralisation (competition policy, state aid). In this most recent period, innovations associated with one of the three originating domains of the new architecture are more and more often proposed for others (such as OMCs in $\mathrm{OH} \& \mathrm{~S}$ and fundamental rights or councils of national regulators attached to agencies in drug authorisation and maritime safety - to mention only examples that we discuss below). This suggests that the actors perceive commonalities to the problems arising in the three domains, and for that reason are confident that variants of the problemsolving architecture that address these commonalities in one setting can be adapted to address them in others.

Notice that the possibility or scope conditions for experimentalist governance are distinct and much broader than the historical contexts from which the new architecture emerged in particular policy sectors and in the EU more generally. The possibility conditions for experimentalist governance are arguably quite minimal: strategic uncertainty, meaning that policy makers recognise that they cannot rely on their strategic dispositions (eg more market vs more plan) to guide action in a particular domain (or equivalently that they do not know how to achieve their declared goals); and a multipolar or polyarchic distribution of power, in which no single actor has the capacity to impose her own preferred solution without taking into account the views of the others. (Of course, actors' perceptions of these conditions are in part subjective, the result of their own analyses of possibilities, and in this sense the possibility conditions as usual in such circumstances are not entirely objective.) Together, these conditions open up the possibility for transforming distributive bargaining into deliberative problem solving through the institutional mechanisms of experimentalist governance.

In what follows we present the new governance institutions as they were designed to be. We are aware that in the life of society and the law, nothing works precisely as designed, and in Part V we will look at how the experimentalist institutions respond to the (anticipated) discovery that implementation can fall short of, and may raise questions regarding the validity of initial goals. Ideally, of course, we would assess the effectiveness of the new institutions as well, but the available evidence does not allow anything like such a comprehensive assessment and none is attempted here. Our aim in

${ }^{15}$ For useful recent overviews of agency development in the EU, see Chiti, op cit $\mathrm{n} 5$ supra; D. Geradin, R. Muñoz and N. Pettit (eds), Regulation through Agencies in the EU: A New Paradigm of European Governance (Edward Elgar, 2005); Geradin and Petit, op cit n 5 supra; R.D. Kelemen 'The Politics of "Eurocratic" Structure and the New European Agencies', (2002) 25 West European Politics 93; R.D. Kelemen, 'The Politics of Eurocracy: Building a New European State?', in N. Jabko and C. Parsons (eds), With US or Against US? European Trends in American Perspective, The State of the European Union 7 (Oxford University Press, 2005). 
this and the next section is to demonstrate a striking and consistent design innovation, and for that purpose what the designers formally intend certainly counts.

\section{A Route 1: Federated Regulation in Privatised Infrastructure}

\section{Telecommunications}

In response to earlier criticisms about lack of accountability of NRAs and risks of fragmentation of the single market, the EU introduced a New Regulatory Framework for electronic communications networks and services in 2002, which consolidates and amends earlier directives going back to late 1980s. ${ }^{16}$ The New Regulatory Framework requires Member States to guarantee independence of NRAs from service providers. It obligates NRAs to promote the interests of citizens (universal service, consumer protection, data privacy) as well as competition, non-discrimination, and development of the single market. NRAs are also instructed to collaborate with National Competition Authorities (NCAs) in identifying and regulating dominant market positions. According to Geradin and Petit, this represents a significant increase in the NRAs' discretionary powers. ${ }^{17}$

This increase in NRA autonomy is balanced by a new set of consultation and cooperation requirements. NRAs must circulate draft measures that could affect the single market to the European Commission and other NRAs, and must take account of the latter's comments. The European Commission may require NRAs to withdraw proposed measures if it considers 'on the basis of detailed and objective analysis' that they may unduly restrict trade in the single market. It may also issue recommendations on harmonised application of the directives; if NRAs choose not to follow them, they must explain their reasoning to the European Commission. Finally, NRAs are expected to coordinate efforts to bring about resolution of disputes.

Review of implementation and the elaboration of revisions to the framework is the joint responsibility of the European Commission and the European Regulators Group for Electronic Communications Networks and Services (established by Commission Decision 2002/627). The latter's chief purpose is to provide an interface between NRAs and the European Commission, so as to promote consistent application of rules, cooperation between NRAs and the Commission, and to serve as a body for reflection, debate, and advice to the Commission. The Directive also establishes a new consolidated comitological committee, empowered to review proposals for the European Commission's exercise of delegated regulatory powers. ${ }^{18}$ As Geradin and Petit observe,

${ }^{16}$ P. Nicolaides, A. Geveke, and A.-M. den Teuling, Improving Policy Implementation in an Enlarged European Union: The Case of National Regulatory Authorities (European Institute of Public Administration, 2003), at 55-58. The New Regulatory Framework comprises four directives, a Framework Directive (2002/21/EC) 'which sets the main principles for regulating electronic communications in the EU and specifies the tasks of the national regulatory authorities'; a Universal Services Directive (2002/22/EC) which 'lays down the rights of the consumers and the obligations of the industry'; an Access Directive (2002/19/EC) which seeks 'to harmonise the rules of access and traffic between telecommunications suppliers'; and an Authorisation Directive (2202/20/EC), which 'simplifies the rules of telecommunications licences': see G.H. Nørgård, 'National Limits to Transnational Networking? The Case of the Danish IT and Telecom Agency', in Egeberg, op cit n 5 supra, at 167-168.

17 A. de Streel, 'The Integration of Competition Law Principles in the New European Regulatory Framework for Electronic Communications', (2003) 26 World Competition Law \& Economics Review 489; Geradin and Petit, op cit n 5 supra, at 16.

${ }^{18}$ On this committee, see http://europa.eu.int/information_society/topics/telecoms/implementation/onp/ index_en.htm (accessed 19 March 2007). 
this arrangement 'provides a good illustration of a new pattern in EC law, which is to give national agencies greater discretionary powers, but to combine this form of decentralisation with cooperation mechanisms designed to create a partnership among the national agencies, but also between the national agencies and the Commission'. ${ }^{19}$

\section{Electricity}

In electricity, the decisive phase of reorganisation begins with a similar rectification of the powers and responsibilities of the NRAs. The European Electricity Regulation Forum, also known as the Florence Process, was created in 1998 to address regulatory needs arising from national implementation of the 1996 Electricity Directive, which required Member States to establish independent NRAs. ${ }^{20}$ A similar Forum known as the Madrid Process has been developed for gas regulation. The objectives of the Florence Process are to provide a platform for 'informal discussion and the open exchange of experience', complementing bilateral follow-up groups between European Commission and national authorities, in order: to ensure 'that emerging differences in domestic approaches do not create barriers to the establishment of an EU internal market in electricity'. ${ }^{21}$ The Florence Forum, which is organised by the European Commission's DG for Energy and Transport, convenes twice a year, bringing together representatives of NRAs, NCAs, and national energy ministries, along with market actors (transmission system operators, electricity industry representatives), consumer groups, energy traders, and outside commercial and academic experts. Additional meetings of smaller specialised Working Groups are held between full Forum sessions, and a Council of European Energy Regulators (CEER) was established to draft guidelines and policy proposals for discussion by the Forum as a whole. ${ }^{22}$

The critical issues so far addressed by the Florence Process are the development of a common tarification system for electricity transmission and establishment of common

${ }^{19}$ Geradin and Petit, op cit n 5 supra, at 16.

20 Nicolaides et al, op cit n 16 supra, at 58-59; B. Eberlein, 'Formal and Informal Governance in Single Market Regulation', in Christiansen and Piattoni, op cit n 3 supra; B. Eberlein, 'Policy Coordination without Centralisation? Informal Network Governance in EU Single Market Regulation', in C.D. Ehlermann and I. Atanasiu (eds), European Competition Law Annual 2002: Constructing the EU Network of Competition Authorities (Hart, 2004); B. Eberlein, 'Regulation by Cooperation: The "Third Way" in Making Rules for the Internal Energy Market', in P. Cameron (ed), Legal Aspects of EU Energy Regulation (Oxford University Press, 2005). Compared to telecoms, electricity/energy regulators have much more varied institutional set-ups across EU. Not all have statutory independence, though most are funded by industry and appointed by government. Courts do not constitute the first stage of appeal in most cases. The division of labour with competition authorities is also more varied. Performance comparisons are thus more difficult. Nonetheless, electricity/energy NRAs share mandates to ensure interconnection and settle disputes. They are also subject to requirements for prior consultation and reporting, mostly to ministers and sometimes to parliaments: see Nicolaides et al, op cit n 16 supra, at 70-71; Geradin and Petit, op cit $\mathrm{n} 5$ supra, at 19.

${ }^{21}$ Quoted in Eberlein (2003), op cit $\mathrm{n} 20$ supra, at 156.

22 The Council of European Energy Regulators (CEER) was established in March 2000 by a memorandum of agreement promoted by the European Commission. It includes regulators from most European countries, including outside EU, and maintains contacts with counterparts in North America and elsewhere. The CEER views itself as a 'focal point for contacts between regulators and EU institutions': quoted in Eberlein (2004), op cit n 20 supra, at 18. It serves as the regulatory counterpart to the European Association of Transmission System Operators (ETSO), and drafts guidelines and policy proposals for discussion by the Florence and Madrid Fora. According to Eberlein (2005), op cit $\mathrm{n} 20$ supra, at 76, the CEER has successfully 'put regulatory addressees under pressure to give reasons for and, subsequently, adjust their positions'. 
rules for allocation and management of grid interconnection capacity. Policy solutions developed in the Forum are then fed into the agenda of the formally competent EU body, the Energy Council of Member States. Comparison of alternative regulatory approaches, as Eberlein reports, plays an important part in generating these policy solutions: '. . . national regime difference provides a greater variety of alternative regulatory models. The dissemination and comparison of diverse regulatory practices make "tacit knowledge" available to other policymakers beyond national borders'. More broadly, he argues, diversity generates greater opportunities for mutual learning, by creating richer stock of experiences to draw on when devising new policies. ${ }^{23}$

This emerging regulatory framework has been revised by the new Electricity Directive (2003/54/EC) and Regulation on Cross-Border Trade in Electricity (1228/2003), which build on concepts developed in the Florence Process. Their chief procedural innovation is to establish a new committee on cross-border trade in electricity, confined to Member State representatives and operating according to comitology rules. It will impose binding rules through qualified majority voting $(\mathrm{QMV})$ in case the Florence Forum deadlocks, thereby creating what we will later term a 'penalty default' in case the deliberators fail to deliberate. ${ }^{24}$ In this spirit, the new regulation 'entrusts the Commission with the power to adopt and amend guidelines on a variety of issues regarding the inter-transmission system operator compensation mechanism', subject to approval by the committee. ${ }^{25}$ The Directive also obliges the European Commission to produce an annual report on implementation of internal market in gas and electricity, with national progress benchmarked across a series of key indicators, using data supplied by a new European Regulators Group. ${ }^{26}$ This revised framework legislation, Eberlein argues, formalises and institutionalises the regulatory cooperation and coordination emerging from the Florence Forum, while preserving the latter's pivotal role as a deliberative space 'where regulatory options can be debated in the open, where both regulators and addressees need to explain and give solid reasons for their positions'. ${ }^{27}$

\section{B Route 2: Networked Agencies \\ 1 Drug Authorisation}

The European Medicines Agency (EMEA, originally the European Agency for the Evaluation of Medicinal Products) was established in 1993, as part of the first wave of new European agencies. According to the Agency's self-description:

${ }^{23}$ Eberlein (2003), op cit n 20 supra, at 161. Examples include comparisons between the UK and Scandinavian Nordpool System in the design of liberalised electricity markets and use of comparative data on market performance of different regulatory approaches, eg on the link between unbundling of transmission system operators and quality of network access arrangements.

${ }^{24}$ For a discussion of penalty defaults and their generalisation in the form of destabilisation regimes, see section IV B below.

25 Geradin and Petit, op cit n 5 supra, at 18.

26 'The Group should . . . help ensure a consistent application in all Member States of the recently adopted new electricity and gas directives as well as the new Regulation on cross-border exchanges of electricity. The group will provide a transparent platform for co-operation between national regulatory authorities and between these authorities and the Commission. All market participants, consumers and end-users will be able to provide input to its activities', available at http://europa.eu.int/comm./energy/electricity/ regulators_group/index_en.htm (accessed 22 March 2007). This body overlaps substantially in membership with that of the CEER, whose informal regulatory role in the Florence Process is thereby officially recognised.

27 Eberlein (2005), op cit n 20 supra, at 86. 
Its main responsibility is the protection and promotion of public and animal health, through the evaluation and supervision of medicines for human and veterinary use. The EMEA coordinates the evaluation and supervision of medicinal products throughout the European Union. The Agency brings together the scientific resources of the 25 EU Member States in a network of 42 national competent authorities. It cooperates closely with international partners, reinforcing the EU contribution to global harmonisation. ${ }^{28}$

EMEA is governed by a Management Board comprising two representatives from the European Commission, two from the Parliament, and one from each Member State (plus observers from participating European Economic Area (EEA) states). Following the 2001-2004 legislative review of the Agency, representatives from organisations of patients, doctors, and veterinarians, but not the pharmaceutical industry itself, were also given seats on the Board. ${ }^{29}$ The Management Board is assisted by four expert or scientific committees, responsible for different classes of medicinal products. ${ }^{30}$ The members of the older expert committees are nominated by the Member States, and are dominated by representatives of national drug authorisation bodies, plus a few co-opted members from national administrations and scientific labs. Newer expert committees, like that for Orphan Medicinal Products (drugs for rare diseases) have a broader and more independent membership, including one representative of the European Commission, three members nominated by the Commission at the Agency's recommendation, three representatives of patient organisations, plus observers from participating EEA countries and relevant scientific organisations/institutes. ${ }^{31}$ These committees combine functions of risk analysis and risk management. As Krapohl observes of the key Committee for Medicinal Products for Human Use: 'The experts who sit in this committee know their domestic regulatory cultures. This gives the committee the political background not only to analyze, but also to judge the risk of pharmaceuticals'. EMEA's expert committees seek to arrive at consensus decisions through deliberation, but voting is not unusual. ${ }^{32}$

EMEA's 'peer review evaluation system' for medicinal products is conducted through a network of some 3,500 European experts nominated by NRAs in EU and EEA Member States. To increase the transparency of its operations, the list of experts and nominating authorities is now available on the internet. Unlike the US Food and Drug Administration (FDA), members of EMEA's expert committees, working parties, and scientific assessment teams 'are not permitted to have any direct financial or other interests in the pharmaceutical industry which could affect their impartiality.

${ }^{28}$ See website available at http://www.emea.eu.int/htms/aboutus/emeaoverview.htm (accessed 19 March 2007).

29 A. Broscheid and J. Feick, 'The 2001-2004 Review of European Pharmaceuticals Authorization and Regulatory Europeanization', unpublished paper (Max Planck Institute for the Study of Societies, Cologne, 2006).

30 The Committee for Medicinal Products for Human Use (CHMP) — formerly the Committee for Proprietary Medicinal Products (CPMP); the Committee for Medicinal Products for Veterinary Use (CVMP); the Committee for Orphan Medicinal Products (COMP), established in 2001; the Committee for Herbal Medicinal Products (HMPC), established in 2004.

${ }^{31}$ Following the recent legislative review, the CHMP may now co-opt five additional experts, nominated by the Agency as well as Member States.

32 S. Krapohl, 'Credible Commitment in Non-Independent Regulatory Agencies: A Comparative Analysis of the European Agencies for Pharmaceuticals and Foodstuffs', (2004) 10 European Law Journal 518, at 534. For an authoritative study of EMEA, which confirms the deliberative character of its decision making based on extensive interviews and internal documents, see B. Hauray, L'Europe du médicament. Politique-Expertise-Intérêts privés (Sciences Po Presses, 2006). We discovered this outstanding book too late to make full use of its findings in this article. 
They are required to make an annual declaration of their financial interests and also any indirect interests which could relate to the pharmaceutical industry. These requirements are intended to ensure that they act in the public interest and in an independent manner'. 33

Yet some commentators argue that EMEA can and should go further in the direction of regulatory transparency. Thus:

even though ... EMEA is known for a more transparent approach as compared to most of its national counterparts in Europe, critical outside observers still maintain that only a very small part of regulatory information is publicly available. These informational deficiencies concern the accompanying documents and data of applications, the assessment and evaluation discussions of the concerned regulatory bodies, especially the [scientific committees], the details of the resulting decisions and their justification, including minority positions. ${ }^{34}$

During the 2001-2004 legislative review, seven members of one of these committees wrote to the European Parliament advocating that the Agency publish minority views so that the public would become aware of internal disagreements. ${ }^{35}$

The EMEA's most important function is to advise the European Commission on the authorisation of innovative new pharmaceutical products for sale in the European single market through the so-called centralised procedure. Companies wishing to market such products in more than one EU Member State send applications directly to EMEA, which offers a judgement about it, based on assessments from the relevant scientific committee, whose rapporteurs work closely with their national agencies, of opinions submitted by the network of external experts. Drug authorisation decisions are then formally taken by the European Commission, subject to scrutiny by standing (comitology) committees of Member State representatives, which can refer disputed cases to the Council (though this has never in fact occurred). The EMEA also maintains a comprehensive EU-wide electronic database for monitoring adverse health effects of authorised drugs, involving regular mandatory reporting by Member State administrations, which compares favourably with similar systems in other countries, including the USA. ${ }^{36}$

In authorising new drugs, the European Commission usually follows the recommendations of the EMEA's expert committees: 'If it does not do so, this has two consequences for the Commission. First, it has to justify the deviation, and cannot do this without having good arguments for it. Second, if the European Commission deviates from the opinion of the expert committee, the decision-making procedure of the standing committee becomes stricter and applies a greater control to the Commission'. These recommendations include risk management as well as risk analysis: 'In fact, the expert committee in the EMEA develops full policy proposals, which are then accepted by the Commission because this is easier than changing them. The proposals are referred to the Member State committee, but are usually not even discussed there'. This comitology committee is unlikely to reject European Commission draft decisions which follow

\footnotetext{
${ }^{33}$ See website available at http://www.emea.eu.int/htms/aboutus/experts.htm (accessed 19 March 2007).

34 J. Feick, 'Regulatory Rationalisation and Legitimation in the Face of Interests, Influence and Institutional De-politicisation: Market Entry Regulation for Pharmaceuticals in the EU', unpublished paper for conference on "Good Governance" in Supranational Market Regulation: How Do Regulatory Institutions Matter?' (University of Bamberg, 16-17 January 2004), at 20.

35 ibid, at 17.

36 R.D. Kelemen, The Rules of Federalism: Institutions and Regulatory Politics in the EU and Beyond (Harvard University Press, 2004), at 148-149.
} 
EMEA recommendations, since its members belong to the same NRAs as those of the Agency's expert committees, and they also need a qualified majority to overturn such decisions. ${ }^{37}$

There is also a decentralised mutual recognition procedure for the authorisation of cross-border marketing of less innovative pharmaceuticals already approved for sale in at least one Member State, under which the EMEA is empowered to resolve disputes through binding arbitration. Very few such arbitration proceedings have in fact occurred. According to Kelemen, this is because 'the mere threat of arbitration has been sufficient to induce Member States to accept one another's authorisation', whereas Feick contends that pharmaceutical companies often choose to withdraw their applications for cross-border marketing rights in the face of objections from other Member States rather than delay the launch of their product and run the risk of an adverse arbitration decision. ${ }^{38}$ As a result of the recent legislative review, the provisions for binding arbitration have been reinforced, through the creation of a formal Coordination Group of high-level representatives from national drug authorisation agencies with powers to impose a settlement if no agreement can be reached between Member States through mediation. These revised rules thus bring the decentralised mutual recognition procedure closer to the centralised procedure in terms of its capacity to unify the European pharmaceuticals market, while at the same time 'strengthen[ing] the network character of regulatory institutions by adding a [new] structure for Member State interaction with supranational authorities'. ${ }^{39}$

\section{Occupational Health and Safety}

Occupational health and safety (OH\&S) has long been regarded as the jewel in the crown' of European social policy. ${ }^{40}$ This was the first sector in which directives could be adopted by QMV, and it still accounts for two-thirds of all EU social policy directives. The breakthrough came through a 'big bang' of legislation enacted between 1987 and 1992, triggered by the Single European Act. This produced a regulatory 'race to the top', in part through 'piecing together of "best practices" of different Member States' by technical policy experts operating within epistemic communities. The result was a broad OH\&S Framework Directive enacted in 1989, which has since generated 17 daughter directives. ${ }^{41}$

The OH\&S Framework Directive gave the European Commission power to propose new legislation and to enact implementing directives (eg adapting regulations to take account of technical change or adjusting occupational exposure limits), subject to non-binding advice from a Tripartite Advisory Committee (comprising representatives from national administrators, unions, and employers' associations) and mandatory

${ }^{37}$ Krapohl, op cit n 32 supra, at 532 and 534-535. The whole process of drug authorisation is also subject to judicial review by the European courts, in light of an extensive body of EU substantive legislation, based on the principle of maximum harmonisation.

${ }^{38}$ Kelemen, op cit n 36 supra, at 147; Feick, op cit n 34 supra, at 6-7, and 17-18.

39 Broscheid and Feick, op cit n 29 supra, at 27. This legally based Coordination Group replaces a pre-existing unofficial Mutual Recognition Facilitation Group that performed similar functions informally. Companies can still avoid binding arbitration by withdrawing their application before the Coordination Group begins its mediation.

40 S. Smismans, Law, Legitimacy, and European Governance-Functional Participation in Social Regulation (Oxford University Press, 2004), at 86; R. Geyer, Exploring European Social Policy (Polity Press, 2000), at $72-80$.

${ }^{41}$ Smismans, op cit n 40 supra, at 104, summarising work by Eichner and others. 
supervision by a comitology committee (composed of Member State representatives). But despite the construction of an impressive body of legislation, EU OH\&S policy has suffered from serious implementation problems, signalled most conspicuously by the Member States' failure to transpose the directives: by 30 June 1994, only one Member State had transposed all OH\&S directives. ${ }^{42}$ Behind this transposition lag lay a series of practical and institutional barriers to harmonisation of $\mathrm{OH} \& \mathrm{~S}$ regulation, arising from national differences in inspection services, unequal availability of scientific data, and non-dissemination of information on standards to parties concerned.

The difficulties of implementing the new $\mathrm{OH} \& \mathrm{~S}$ legislation provoked a series of overlapping strategic responses from the EU institutions over the past decade, which have pushed the Community's regulatory framework increasingly in the direction of networked governance. The first response was a determined compliance campaign by the European Commission, which sent 30 'reasoned opinions' to Member States about their performance in this area, took nine decisions to refer recalcitrant Member States to the European Court of Justice (ECJ), and obtained four court rulings against them for failure to correctly implement the directives. At one level, this campaign was remarkably successful, yielding a $95 \%$ rate of compliance with existing directives by $1999 .{ }^{43}$ At another level, however, these very successes pointed up the intrinsic limitations of a European Commission-led judicial enforcement strategy for overseeing the ongoing operation of Community OH\&S regulation. For as Smismans points out in his authoritative study:

... [T] he Commission lacks the necessary resources to ensure control over whether the Member States have de facto taken all the necessary measures - let alone control over de facto application. Moreover, even if the Commission had the necessary resources to monitor practical implementation on a routine basis, it would not be able to act through the ECJ without imposing an impossible burden on the Court. ${ }^{44}$

A second strategic response to the problems of implementing EU OH\&S legislation has been the networking of national health and safety inspectorates. The key move here was the establishment in 1995 of a Committee of Senior Labour Inspectorates (SLIC), formalising an earlier group which had been meeting since 1982. This body is responsible for assisting the European Commission on all problems relating to enforcement by Member States of European OH\&S law. SLIC's role has been accentuated in the new Community OH\&S Strategy for 2002-2006, which charges the committee with encouraging 'exchanges of information and experience and organising mutual cooperation and assistance' among national labour inspectorates, in order to develop common principles, objectives, and evaluation methods for OH\&S inspection systems, based on a preventative and multi-disciplinary approach. ${ }^{45}$

The third strategic response was the creation of a networked information agency, the European Agency for Safety and Health Protection at Work, generally known from its location as the Bilbao Agency. This body was established in 1994, to fill information gaps associated with weak implementation of OH\&S directives by collecting and

42 ibid, at 107 .

43 ibid, at 113 .

${ }^{44} \mathrm{ibid}$, at 114. Over the past decade, moreover, the European Commission's internal monitoring capacity for OH\&S has been substantially reduced by diversion of resources to the Bilbao Agency (see below) and new public health activities.

45 ibid, at 112-113, 114-115 and 434; European Commission, Adapting to Change in Work and Society: A New Community Strategy on Health and Safety at Work 2002-2006, COM (2002) 118 final, Brussels, 11 March, at 10-11. 
disseminating information, supporting cooperation and exchanges of experience among Member States, advising Community institutions (especially the European Commission), and coordinating a network of National Focal Points (NFPs), expert groups, topic centres, and international contacts. The Agency is governed by a tripartite board with representatives from Member State governments, trade unions, employers' organisations, and the European Commission, with double voting power for government representatives. Each Member State is responsible for creating an NFP to interface with the agency: 'The Focal Points are the key players in the network of the Agency; they are responsible for the organisation and coordination of the national network and ensure the transmission of information from and to the Agency'. NFPs can be led by an independent agency or a ministerial division, with various intermediate arrangements. Two-thirds of NFPs have tripartite advisory committees; social partner peak associations, semi-public prevention institutions, and private consultants are normally part of the network, but only some Member States also include nongovernmental organisations (NGOs), charities, professional associations and private firms. The Agency also convenes Expert Groups on specific thematic issues (eg monitoring, good practice, research), whose members are normally nominated by NFPs, and can commission contract research from institutional Topic Centres with special expertise in particular areas (eg stress at work). ${ }^{46}$

The creation of the Bilbao Agency has led to the reshaping, intensification and formalisation of European and national OH\&S networks. But careful study of its operations has uncovered some significant limitations to the effectiveness of networked governance in this sector. Thus the Agency claims that 'the Commission has often used [its] channels . . . to consult the Member States beyond the usual procedures' ${ }^{47}$ But Smismans contends that this is not borne out by his interviews, which show weak influence of the Agency on the European Commission's decision making. Information compiled by the Agency does not necessarily fit with European Commission's priorities, and there is insufficient coordination between them. Smismans also claims that the information collected by the Agency is not necessarily reliable, because it is compiled from material supplied by the national administrations, and does not reach a wide audience of practitioners within industry. According to one interviewee, Member State representatives' main concern is that their national position is correctly represented in the Agency's overall report. They 'are hardly interested in the reports of the other Member States or in the coherence of the final Agency report'. ${ }^{48}$

One key problem is the burden of network participation on NFPs, 'which often lack the necessary resources to reply to the Agency's requests. Apparently many Member States do not consider the work of the Agency as a priority, or worse, see it as a possible "intrusion" into their administration'. Another major problem is the dominant position of national administrations within the networks, who appear as 'both interested party and judge' on the question of implementation of EU OH\&S standards. ${ }^{49}$ The practical effects of this dominance are exacerbated by Member States' understandable reluctance to provide information on bad implementation since, as Smismans observes, 'they are afraid that the Commission may use this information against them

\footnotetext{
46 Smismans, op cit $\mathrm{n} 40$ supra, at 268, 284 and 287.

${ }^{47}$ Quoted in ibid, at 293.

48 ibid, at 294.

49 ibid, at 295.
} 
in court proceedings' ${ }^{50}$ Nor can it be demonstrated that the Agency has contributed to improved implementation of EU legislation, since it does not ensure a system of monitoring at Member State level. A thematic network group on OH\&S monitoring was created in 1999 at the request of the trade unions, but it has since been allowed to lapse, and only limited activities are currently being conducted in this area. ${ }^{51}$

Both the social partners and the European Commission have recently proposed to overcome these limitations of networked governance in OH\&S policy through the application of an OMC. Thus in its Community OH\&S Strategy for 2002-2006, the European Commission advocated the incorporation of national-level quantitative targets for OH\&S into the European Employment Guidelines, and the revised 20032005 guidelines included a reference to the policy goal of ensuring 'a substantial reduction in the incidence rate of accidents at work and of occupational diseases'. At the same time, the European Commission also called for an enhanced role for the Bilbao Agency in organising exchanges of experience and information through systematic data collection, and establishment of a 'risk observatory', based on firm and industry examples of good practice. Social partner representatives on the European Economic and Social Committee, by contrast, have argued in favour of applying the $\mathrm{OMC}$ to $\mathrm{OH} \& \mathrm{~S}$ policy through a new freestanding process. ${ }^{52}$

The establishment of such an OMC process, Smismans argues, would allow publicly debated guidelines to be set for reductions of workplace risks and hazards or for the standards of health and safety services. Member States would have to report annually on their efforts to reach these targets, be evaluated at EU level, and be subject to recommendations from the European Commission and the Council. "Although not a system of legally binding duties that are controlled and could be enforced with sanctions, this strong-soft monitoring system is likely to have a better outcome than the current "voluntary" soft-soft approach of the Agency's "governance by information"'. It could also create new roles for the Bilbao Agency in ensuring the compatibility of national $\mathrm{OH} \& \mathrm{~S}$ data, coordinating the reporting process, and ensuring the quality of the information provided by national networks. ${ }^{53}$

\section{Route 3: The Open Method of Coordination}

The recursive properties of the EU's new experimentalist governance architecture are displayed most clearly in the family of processes known as the OMC, which are also most distant from classic forms of law making. The OMC grew out of the EU's experience with the coordination of national economic and especially employment policies during the 1990s, but was inaugurated as a new and broadly applicable governance instrument at the extraordinary Lisbon European socio-economic summit in March 2000. Since then, this method has been extended to cover an enormous range of policy fields. Beyond the Broad Economic Policy Guidelines (BEPG) introduced by the Treaty of Maastricht (1992), and the European Employment Strategy (EES) inaugurated by the Treaty of Amsterdam (1997), the OMC has become the central tool of EU

${ }^{50}$ S. Smismans, 'Towards a New Community Strategy on Health and Safety at Work? Caught in the Institutional Web of Soft Procedures', (2003) 19 International Journal of Comparative Labour Law and Industrial Relations 55, at 70.

${ }^{51}$ Smismans, op cit $\mathrm{n} 40$ supra, at 296.

52 ibid, at 302, n 185.

53 ibid, at 303-304. 
social policy making in the new millennium, with formal coordination processes launched for social inclusion and pensions in 2001-2003, and another now underway for health care and long-term care of the elderly. As part of the 'Lisbon Strategy' aimed at turning the EU by 2010 into 'the most competitive and dynamic knowledge-based economy in the world capable of sustainable economic growth with more and better jobs and greater social cohesion', the March 2000 European Council authorised the extension of the OMC to a host of other policy areas, such as research/innovation, information society/eEurope, enterprise promotion, structural economic reform, and education and training. Since then, OMC processes have also been proposed by the European Commission and other European bodies as mechanisms for monitoring and supplementing existing EU legislative instruments and authority in fields such as immigration and asylum, environmental protection, disability, OH\&S, and even fundamental rights, as well as in areas like youth policy where the EU has few if any legal powers. ${ }^{54}$ In addition, following recommendations from the European Commission's High Level Group on Industrial Relations, the European social partner organisations have drawn inspiration from the OMC for the monitoring and follow-up of nonbinding framework agreements and guidelines at both cross-industry and sectoral levels. ${ }^{55}$

The OMC was defined by the Portuguese Presidency at Lisbon and afterwards in terms closely modelled on the EES as involving a specific ensemble of elements:

- Fixing guidelines for the Union combined with specific timetables for achieving the goals which they set in the short, medium and long term;

${ }^{54}$ For overviews of the scope and applications of the OMC across different policy areas, see S. Borrás and K. Jacobsson, 'The Open Method of Co-ordination and New Governance Patterns in the EU', (2004) 11 Journal of European Public Policy 185; C. Radaelli, The Open Method of Coordination: A New Governance Architecture for the European Union? Swedish Institute for European Policy Studies, Stockholm, Sieps Report no 1, March 2003; G. de Búrca, 'The Constitutional Challenge of New Governance in the European Union', (2003) 28 European Law Review 814; J. Zeitlin and P. Pochet with L. Magnusson (eds), The Open Method of Coordination in Action: The European Employment and Social Inclusion Strategies (P.I.E.-Peter Lang, 2005). On the OMC in research/innovation, immigration/asylum, and occupational health and safety respectively, see R. Kaiser and H. Prange 'Managing Diversity in a System of Multilevel Governance: The Open Method of Co-ordination in Innovation Policy', (2004) 11 Journal of European Public Policy; A. Caviedes, 'The Open Method of Co-ordination in Immigration Policy: A Tool for Prying Open Fortress Europe?', (2004) 11 Journal of European Public Policy 289; Smismans, op cit n 50 supra. For proposals that the OMC be used for the implementation of fundamental rights, see section III D 2 below. A number of pre-existing European policy coordination processes have also been retrospectively interpreted as full or partial examples of the OMC avant la lettre, including the Cardiff Process for structural economic reforms, the Bologna Process for cooperation in European higher education, and the code of conduct against harmful tax competition: on these, in addition to the surveys cited above, see D. Foden and L. Magnusson (eds), Trade Unions and the Cardiff Process: Economic Reform in Europe (European Trade Union Institute, 2002); A. Hingel, Education Policies and European Governance: Contribution to the Interservice Groups on European Governance, European Commission, DG for Education and Culture, Brussels, March 2001; and C. Radaelli, 'The Code of Conduct Against Harmful Tax Competition: Open Method Of Coordination In Disguise?', (2003) 81 Public Administration 513, respectively.

55 European Commission DG EMPL, Report of the High Level Group on Industrial Relations and Change in the European Union, January 2002. Agreements concluded so far have focused on the issues of teleworking and work-related stress. For overviews of current developments, see European Commission DG EMPL, Industrial Relations in Europe 2004 (Office for Official Publications of the European Communities, 2004); D. Obradovic, Civil and Social Dialogue in EU Governance, NEWGOV Deliverables 24 D1, University of Amsterdam, 25 May 2005. 
- establishing, where appropriate, quantitative and qualitative indicators and benchmarks against the best in the world and tailored to the needs of different Member States and sectors as a means of comparing best practices;

- translating these European guidelines into national and regional policies by setting specific targets and adopting measures, taking into account national and regional differences;

- periodic monitoring, evaluation and peer review organised as mutual learning processes. ${ }^{56}$

But actual OMC processes as they have evolved since Lisbon vary considerably in their modalities and procedures, depending on the specific characteristics of the policy field in question, the Treaty basis of EU competence, and the willingness of the Member States to take joint action. Thus, for example, the European Commission and the Council are empowered to issue joint recommendations to Member States on the implementation of the EES and the BEPGs, but not on that of other OMC processes, while consultation of the European Parliament is formally required only in the case of the EES. Although most OMC processes are based on common European objectives, only the EES and BEPG involve detailed guidelines for their realisation by Member States. Common European statistical indicators or benchmarks have been established for economic policy, structural reforms, employment, social inclusion, and education, but not yet for pensions or health care. The BEPGs, backed by the Stability and Growth Pact, notoriously impose national ceilings on government deficits and public debt as a proportion of gross domestic product (GDP); the EES has fixed European employment rate targets, disaggregated by age and gender, which some countries have translated into nationally specific objectives; and the Social Inclusion OMC calls upon Member States to set national targets for the reduction of relative income poverty. ${ }^{57}$ Member States prepare National Action Plans (NAPs) for employment and social inclusion, and National Progress Reports on structural economic reforms, but so far only more limited 'National Strategy Reports' on pensions. These national plans and reports are subjected to mutual surveillance and peer review by Member State representatives in the Employment Committee (EMCO), Social Protection Committee (SPC), and Economic Policy Committee (EPC) respectively, while active programs for mutual learning through exchange of good practices (also confusingly termed 'peer review') have been organised within the framework of the EES and the Social Inclusion process. Other so-called OMC processes are more loosely structured, notably those in fields such as research/innovation, information society/eEurope, enterprise promotion, and structural economic reform, involving only selective elements of the broader method, such as scoreboards, peer evaluation, and exchange of good practices. ${ }^{58}$

${ }^{56}$ Lisbon European Council Presidency Conclusions, 23-24 March 2000, §37.

57 The Barcelona European Council of 15-16 March 2002 also fixed national childcare and R\&D investment/GDP targets for Member States as part of the EES and innovation policy OMC respectively. The 2003-2005 employment guidelines included additional quantitative targets at national level for combating early school leaving and promoting participation in lifelong learning, see Council of the European Union, Council Decision of 22 July 2003 on Guidelines for the Employment Policies of the Member States, [2003] OJ L 197/13.

${ }^{58}$ For an insightful analysis of the limited application of OMC in these areas, see Tavistock Institute, London; Net Effect Ltd, Helsinki, and Istituto per la ricerca sociale, Milan, The Analysis of Impacts of Benchmarking and the eEurope Actions in the Open Method of Co-ordination. How the eEurope OMC 
The OMC was envisaged by its architects as a 'third way' for EU governance between regulatory harmonisation and fragmentation, capable of reconciling the pursuit of common European objectives with respect for national diversity while encouraging mutual emulation and experimental learning through comparison of different approaches to shared problems. ${ }^{59}$ In the years following the Lisbon Summit, the OMC therefore appeared to have become the governance instrument of choice for EU policymaking in complex, domestically sensitive areas, where diversity among the Member States precludes harmonisation but inaction is politically unacceptable, and where widespread strategic uncertainty recommends mutual learning at the national as well as the European level.

From the very outset, however, the OMC's innovative architecture and its apparent lack of conformity to canonical models of EU law making aroused fierce controversies about the method's democratic legitimacy, practical effectiveness, and implications for European integration. ${ }^{60}$ In the spring of 2005, amidst widespread concern about the limited progress of EU Member States towards meeting the Lisbon targets, the incoming Barroso Commission proposed a 'new start' for the Strategy, based on narrowing its focus to growth and employment, integrating the economic policy and employment guidelines, and replacing sectoral, multilateral policy coordination by integrated, bilateral dialogues on national reform programs between the European Commission and the individual Member States. But following a successful public campaign spearheaded by social NGOs with support from key Member States and the European Parliament, the social cohesion objectives of the Lisbon Strategy were reinstated by the spring European Council, and the continuation of the OMC in social protection and inclusion explicitly reaffirmed. From 2006, common European objectives have been formulated across the three 'pillars' of social inclusion, pensions, and health/elder care, and progress towards them monitored through an integrated set of OMC processes, whose results are to be 'fed into' the revised Lisbon Strategy at both Member State and EU level through the national reform programs and annual progress review at the spring European Council. Despite the Barroso Commission's declared preference for bilateral dialogue rather multilateral policy coordination, moreover, it has continued to propose new OMC processes when faced with the perceived need for joint action in politically sensitive, institutionally diverse policy fields, from improving regulation and reducing administrative burdens to promoting local and regional clusters. ${ }^{61}$

Worked: Implications for the Co-ordination of Policy under i2010, final report prepared for DG Information Society, European Commission, 2005.

${ }^{59}$ See the sources cited in J. Zeitlin, 'The Open Method of Co-ordination in Question', in Zeitlin and Pochet, op cit n 54 supra, at 22-23.

${ }^{60}$ For a comprehensive review of these controversies and the available empirical evidence about the OMC's performance in the fields of employment and social inclusion, see Zeitlin and Pochet, op cit n 54 supra; J. Zeitlin, 'Social Europe and Experimentalist Governance: Towards a New Constitutional Compromise?', in G. de Búrca (ed), EU Law and the Welfare State: In Search of Solidarity (Oxford University Press, 2005).

${ }^{61}$ See European Commission, Working Together for Growth and Jobs: A New Start for the Lisbon Strategy, COM (2005) 24, Brussels, 2 February; European Commission, Working Together, Working Better: A New Framework for the Open Coordination of Social Protection and Inclusion Policies in the European Union, COM (2005) 706 final, Brussels, 22 December; C. Radaelli, 'Whither "Better Regulation" for the Lisbon Agenda?', (2007) 14 Journal of European Public Policy 190. 


\section{Extensions of the New Architecture ${ }^{62}$}

\section{A Response to Catastrophe}

\section{Food Safety}

The European Food Safety Authority (EFSA) was established in 2002 in wake of the BSE and dioxin scandals. From the outset EFSA was conceived as the agenda-setting hub of an interactive network linking together EU institutions (especially but not exclusively the European Commission), NRAs, scientific experts, and producers across the Member States. Already, according to one close and critical observer of its operations, this network has developed 'a sophisticated politics of hazard', involving 'meaningful systems of multiple accountability and mutual veto, and a highly reflexive market place of ideas'. ${ }^{63}$

EFSA's mission, as set out in the authorising regulation, focuses on providing 'scientific advice and scientific and technical support for the Community's legislation'; collecting and analysing data 'to allow the characterisation and monitoring of risks which have a direct or indirect impact on food and food safety'; and supplying 'scientific opinions which will serve as the scientific basis for the drafting and adoption of Community measures'. As the regulation explicitly specifies, these tasks should be undertaken in conditions that respect the virtues of 'independence', 'scientific and technical quality', 'transparency' and 'diligence'. EFSA is responsible for orchestrating cooperation between the Agency, the European Commission, and the Member States in order to 'promote effective coherence between risk assessment, risk management and risk communication' ${ }^{64}$ As the Authority's first Executive Director emphasised, this cooperation should be not only vertical, between the Member States and EFSA, but also horizontal, among the Member States themselves:

We should encourage the various national authorities to spend more time talking to each other because they often face common problems. There may be no need for EFSA to intervene in many of these

${ }^{62}$ As with our presentation of the initial routes to the EU's new governance architecture, these examples of pathways to its extension are illustrative rather than exhaustive. Other recent extensions combine elements of the pathways discussed below. Thus, for instance, the European Railway Agency and its affiliated network of National Regulatory Bodies (established in 2004) deal with both safety and interoperability issues; the Article 29 Working Group of National Data Privacy Authorities (established in 1997) integrates the protection of individual privacy rights directly into the construction of rules for transnational commerce within and beyond the EU; while the reform of the Common Fisheries Policy, another highly centralised and supranationalised policy area, has resulted in the creation first (in 2002) of Regional Advisory Councils open to stakeholders, scientists, and national authorities, and then (in 2005) of a Community Fisheries Control Agency to coordinate national implementation and enforcement of the reformed rules. On railways, see the ERA website available at http://www.era.europa.eu/ (accessed 19 March 2007); on data privacy, B. Eberlein and A. Newman, Innovating EU Governance Modes and the Regulatory Dilemma: The Rise of Incorporated Transgovernmental Networks, unpublished paper presented to the 15th International Conference of Europeanists, Chicago, Illinois, 29 March-2 April 2006, at 211-216; on fisheries, C. Lequesne, 'Fisheries Policy', in Wallace et al, op cit n 7 supra; Regional Advisory Councils webpage available at http://ec.europa.eu/fisheries/cfp/governance/racs_en.htm (accessed 19 March 2007); Community Fisheries Control Agency webpage available at http://ec.europa. eu/cfca/index_en.htm (accessed 19 March 2007).

${ }^{63}$ D. Chalmers, 'Risk, Anxiety and the European Mediation of the Politics of Life', (2005) 30 European Law Review 649, 650; cf K. Vincent, "'Mad Cows" and Eurocrats: Community Responses to the BSE Crisis', (2004) 10 European Law Journal 499, at 517.

${ }^{64}$ Quoted in Vincent, ibid, at 515. 
issues. . . There are good reasons for sharing resources. Member States increasingly discover that the food issues they are dealing with have already arisen somewhere else in the European Union. ${ }^{65}$

EFSA is overseen by a Management Board whose members are appointed 'on the basis of their individual expertise and competence' by the Council in consultation with the European Parliament from a list of nominees drawn up by the European Commission. 'None of them represents any government, organisation or sector', but four of the fourteen members 'have backgrounds in organisations that represent consumers or other interests in the food chain'. ${ }^{66}$ 'All Board meetings can be viewed on the EFSA website and some are also open to the public, in line with the Authority's commitment to openness and transparency'. An Advisory Forum of representatives from Member State food safety authorities assists the Executive Director in establishing the Authority's priorities and work programme. According to the Authority's website, this body is 'an important forum for exchange on risk assessment and food safety issues, including assistance in the identification of emerging issues . . . and may also resolve contentious scientific disputes through discussion' ${ }^{67}$ EFSA's scientific work is undertaken by a series of panels, each responsible for a different aspect of food safety, coordinated by an overarching Scientific Committee. Both the Panels and the Scientific Committee consist of leading independent scientists, often university professors, appointed by the Management Board, not the Member States. The Scientific Committee and panels may answer requests from European institutions, such as the European Commission or European Parliament, from the Member States or undertake work on the Authority's own initiative. ${ }^{68}$

Unlike in pharmaceuticals, EU food safety regulation formally separates risk analysis (the province of EFSA and its scientific committee) from risk management (the responsibility of the European Commission). But if the European Commission deviates from EFSA's advice, it is normally obliged to provide a formal explanation of its reasons for so doing. ${ }^{69}$ On sensitive issues, such as the authorisation of genetically modified organism (GMO) foodstuffs, the European Commission invariably follows the opinion of the EFSA scientific panel. Thus as Chalmers points out, 'The Commission has ... adopted, uncontested, all eight Opinions that the EFSA has provided in this field' ${ }^{70}$ Regulatory decisions by the European Commission must also pass through

${ }^{65}$ G. Podger, 'European Food Safety Authority Will Focus on Science', (2004) 5 European Affairs (online journal published by the European Institute, Washington, DC), website available at http://www. europeanaffairs.org/archive/2004_winter/2004_winter.php4 (accessed 14 July 2007).

${ }^{66}$ Krapohl, op cit $\mathrm{n} 32$ supra, at 531.

${ }^{67}$ See website available at http://www.efsa.europa.eu/en/mboard.html (accessed 19 March 2007); and http:// www.efsa.europa.eu/en/advisory_forum.html (accessed 19 March 2007).

${ }^{68}$ Krapohl, op cit n 32 supra, at 531-532.

69 We are grateful to Professor Ellen Vos of Maastricht University for expert advice on this point. For a contrasting view, see Krapohl, op cit n 32 supra, at 531-533.

70 Chalmers, op cit n 63 supra, at 652-653. The recently introduced procedure for authorisation of genetically modified food and feed (New Regulation 1829/2003/EC) represents a shift from something like the decentralised mutual recognition arrangement in pharmaceuticals to something closer to the EMEA's centralised authorisation procedure. Thus EFSA rather than the notified national authority is now empowered to make the initial risk evaluation, while other Member States and the European Commission only have to be informed by the Authority when it receives an application for authorisation. The European Commission is then responsible for proposing risk management action based on EFSA's risk analysis. As in food safety more generally, EFSA and the NRAs are expected to cooperate in investigation and risk assessment. For analyses of the new procedure, whose operation remains highly contested, see E. Brosset, 'The Prior Authorisation Procedure Adopted for the Deliberate Release into the 
the Standing Committee on the Food Chain and Animal Health, composed of Member State representatives from national ministries, established in 2002 following the new comitology regulatory procedure, under which the European Parliament must be kept informed at every stage. Although this procedure requires a qualified majority to refer European Commission proposals to the Council, unlike in pharmaceuticals, it operates through face-to-face meetings rather than comment on written proposals, which reduces the costs of raising objections and enhances deliberation. ${ }^{71}$

\section{Maritime Safety}

The European Maritime Safety Agency (EMSA) was established in 2002, following a series of high-profile disasters, such as the sinking of the Estonia ferry and the Erika and Prestige tankers, and the enactment of a substantial package of new EU legislation. ${ }^{72}$ The Agency's main objectives are to ensure a high, uniform and effective level of maritime safety and prevention of pollution by ships within the Community; and to reduce the risk of maritime accidents, marine pollution from ships and the loss of human lives at sea. Its specific mission is to "provide technical and scientific advice to the Commission in the field of maritime safety and prevention of pollution by ships in the continuous process of updating and developing new legislation, monitoring its implementation and evaluating the effectiveness of the measures in place'. The Agency's central activities include: strengthening the Port State Control regime; auditing Community-recognised classification societies; developing a common methodology for the investigation of maritime accidents; and establishing a Community vessel traffic monitoring and information system.

EMSA's Administrative Board consists of one representative from each Member State and four representatives from the European Commission, along with 'four professionals from the sectors most concerned', nominated by the European Commission, without voting rights. Member State representatives typically come from Ministries of Transport or national maritime authorities. Administrative Board minutes are posted on the Agency's website, and there is an individual right of appeal against refusal to supply documents.

Like other networked agencies, EMSA officials are expected to work closely with Member States maritime services, facilitate horizontal cooperation between them, and disseminate best practices. The Agency:

will respond to [Member States'] specific requests in relation to the practical implementation of Community legislation, such as the recently adopted directive on traffic monitoring, and may organise appropriate training activities. . . The Agency will also play a positive role in the process of European Union enlargement, by assisting the accession countries in the implementation of Community legislation on maritime safety and the prevention of pollution by ships.

The Agency is further responsible for contributing to the evaluation and implementation of Community legislation 'by providing the Commission and the Member States with objective, reliable and comparable information and data on maritime safety and

Environment of Genetically Modified Organisms: the Complexities of Balancing Community and National Competences', (2004) 10 European Law Journal 555; M. Pollack and G. Shaffer, 'Biotechnology Policy', in Wallace et al, op cit n 7 supra; and especially P. Dabrowska, Hybrid Solutions for Hybrid Products? EU Governance of GMOs, unpublished PhD thesis, Department of Law, European University Institute, Florence, 2006.

${ }^{71}$ Krapohl, op cit $\mathrm{n} 32$ supra, at 533.

72 Legal basis: Regulation (EC) No 1406/2002, amended 2003-2004. 
on ship pollution' and by orchestrating 'an ongoing process of dialogue and cooperation' between the European Commission and national maritime authorities of the EU and participating EEA states. ${ }^{73}$

\section{B Prudential Regulation in Advance of Failure: Financial Services}

Beginning in 2001, the EU adopted a new regulatory approach known as the Lamfalussy Package to accompany the raft of legislation enacted under its Financial Services Action Plan (39 directives passed between 1999 and 2004). The aim of this initiative was to establish a comprehensive structure of financial supervision in the wake of the introduction of the euro, and in light of the limited oversight powers of the European Central Bank. As Lannoo and Casey point out:

The EU managed to reform the structure of financial regulation and supervision in a consensual and rapid way, which has surprised many observers. Perhaps the most remarkable element of the reform was the manner of its advent: as opposed to being catalyzed by a crisis (as one would have expected), the reform arose endogenously as a response to market developments. ${ }^{74}$

The Lamfalussy Report's central recommendations were 'the need for framework legislation, broad implementing powers for committees, strengthened cooperation between national regulators and stronger enforcement'. These recommendations gave rise to a four-level regulatory approach: ${ }^{75}$

1. The agreement of broad framework principles for legislation at EU level, based on a proposal from the European Commission to the Council and the Parliament, following wide consultations.

2. The development of detailed EU rules for implementing these framework principles by the European Commission in consultation with Member State representatives through a series of new sectoral comitology committees (covering securities, banking, insurance, and financial conglomerates respectively).

3. Networked cooperation between national regulators through so-called 'level-3 committees' to ensure more consistent implementation of Community law at Member State level. ${ }^{76}$ These sectoral committees of regulators are responsible for producing guidelines for national implementation, 'in order to set best practice, conduct peer reviews, and develop joint interpretative recommendations and standards for matters not covered by EU law.... [They] have no implementing powers, but advise the European Commission on level-2 measures'.

4. Greater attention to the enforcement of Community law by the European Commission, with cooperation from Member States and their regulators.

This whole structure is overseen by a pair of high-level EU advisory committees, like those responsible for organising OMC processes. These are composed of an equal

${ }^{73}$ For this and previous citations, see website available at http://www.emsa.europa.eu/end179d002.html (accessed 19 March 2007). There is as yet little scholarly literature on the EMSA.

${ }^{74}$ K. Lannoo and J.-P. Casey, EU Financial Regulation and Supervision beyond 2005, CEPS Task Force Report 54, Centre for European Policy Studies, Brussels, January 2005, at 51.

$75 \mathrm{ibid}$, at 2 . See also the flow chart of procedures and committees, at 4-5, figures 1-2.

${ }^{76}$ There are separate Committees of European Regulators for securities, banking, insurance and occupational pensions, supplemented by a Cross-Sectoral Roundtable. 
number of representatives from each Member State and the European Commission, which also supplies their secretariat. The Economic and Financial Committee (EFC) remains the primary source of advice to the Council and European Commission on financial stability; a new Financial Services Committee is responsible for providing advice on financial market regulatory issues and coordinating the work of the sectoral comitology committees. ${ }^{77}$

A crucial feature of the new arrangements, as Lannoo and Casey emphasise, is increased horizontal cooperation among national regulators:

\footnotetext{
Not only do ministry of finance representatives have to sit together when discussing draft directives, supervisors now also meet to discuss implementing measures. Although supervisors had already been meeting before, this was largely limited to the presidents of the supervisory commissions, in the context of the pre-Lamfalussy regulatory committees. Today, the specialists also meet on a regular basis in ad-hoc committees dealing with specific matters. This development should certainly have a positive effect on the quality of European financial regulation and on levelling the regulatory playing field. It increases the degree of regulatory harmonisation and reduces the possibility for host-country restrictions. At the same time, supervisors are aware that their respective financial centres are in competition with each other and that they need to ensure that regulation is in line with market needs. ${ }^{78}$
}

Despite the advantages of the new networked, multi-level regulatory framework, some major problems remain. First, increased transparency and accessibility have come at expense of complexity and possible domination by large states/producer interests. Second, the distinction between broad framework legislation and delegated implementing regulation has proved difficult to apply in practice, mainly because the European Parliament and the Member States have been reluctant to allow sufficient discretion to the level-2 decision-making process where the European Commission holds most of the cards. Hence there have been numerous complaints from financial market actors that many of the new securities regulation directives are excessively detailed and burdensome, exacerbated by their tendency to impose maximum rather than minimum harmonisation standards in order to prevent Member States from creating new trade barriers by imposing additional host country requirements for cross-border provision of financial services..$^{79}$

But recent financial market legislation, such as the occupational pension funds directive (2003/41/EC), more closely approximate the new breed of framework regulation envisaged under the Lamfalussy Process. Unlike its predecessors in banking and life insurance, the pension funds directive is principles-based, setting down basic objectives, rules, and parameters, rather than imposing detailed prescriptive requirements. Each Member State 'remains free to define what it expects of an occupational pension', based on its own social policy commitments; but the EU 'regulates how providers will deliver it', allowing pension funds to benefit from free movement of capital and service provision in the internal market, while simultaneously establishing rigorous prudential standards for the protection of their members and beneficiaries. To make this approach work, and resolve the many questions arising about how to draw the line "between the requirements of the single market rules applying to the provider and those of a Member State's social policy on the product', the directive imposes a general obligation on Member States to ensure its uniform application through the development of 'closer

77 Lannoo and Casey, op cit n 7 supra, at 6.

78 ibid.

79 ibid, at 7 and 9-10; R.D. Kelemen, 'Suing for Europe: Adversarial Legalism and European Governance', (2006) 39 Comparative Political Studies 101, at 117-118. 
cooperation and best practices' based on 'regular exchanges of information and experience': Article 21(1). These obligations have given rise to the creation of 'transposition groups' of national regulators, working alongside the permanent Committee of European Insurance and Occupational Pensions Supervisors (CEIOPS), which according to one prominent participant, 'are demonstrating that the levels of trans-national co-operation that the pension fund directive requires to be effective are practicable' ${ }^{80}$

\section{Rationalisation of Existing Centralised Regulation}

\section{Competition Policy}

Competition policy is historically one of the most centralised parts of the EU system, with the strongest upwards transfer of power from the Member States to the European Commission and the Court, especially in protecting the internal market against interfirm restrictive agreements (Article $81 \mathrm{EC}$ ) and the abuse of a dominant position by individual firms (Article 82 EC). Until the Modernisation of EC Antitrust Enforcement Rules Package of 2003-2004, all claims for exemption of inter-firm agreements from prohibition under Article 81(3) had to be notified to and adjudicated by the European Commission, which was also empowered (alongside national courts and Member State competition authorities) to issue injunctions and levy fines on firms involved in illegal agreements or abusing a dominant market position, subject to review by the ECJ. This system generated a number of major problems, notably a growing administrative bottleneck created by requests from firms to the European Commission for exemption of agreements under Article 81(3) and overlapping jurisdictions/potential conflicts between the European Commission and national competition law authorities.

The 2003-2004 reforms created a new unified, decentralised, and networked system of governance for EU antitrust regulation. ${ }^{81} \mathrm{EC}$ competition law was unified through the creation of an exclusive zone of application, in which only European rules henceforth apply to agreements capable of affecting trade between Member States. Antitrust regulation was simultaneously decentralised by empowering NCAs and courts to apply Article 81 directly, abolishing the requirements for prior notification and adjudication of requests for exemption by the European Commission. Finally, this newly decentralised system of regulation was networked through the establishment of formal cooperative arrangements and consultation procedures between the European Commission and NCAs on the one hand and between the Commission and national courts on the other, designed to ensure a consistent application of Community competition law. Thus a European Network of Competition Authorities was created within which the European Commission and the NCAs can work together in dealing with anti-competitive practices through mutual consultation and information exchange

80 Jaap Maassen, Chairman of the European Federation for Retirement Provision/Director of the Dutch Government Employees' Pension Fund (ABP), 'EU Pension Directive Should Be Welcomed: Delays in Notification Do Not Signify Failure', Financial Times, 3 October 2005. On the mutually supportive relationship between the Directive and the objectives of the OMC pensions process, see also D. Natali, 'The European Union and Pensions: Recent Steps in "Hard" Legislation and "Soft" Co-ordination', in C. Degryse and P. Pochet (eds), Social Developments in the European Union 2004 (European Trade Union Institute for Research, Education, Health and Safety, the Observatoire Social Européen, and SALTSA, 2004), at 218-219.

${ }^{81}$ D. Geradin, 'Competition between Rules and Rules of Competition: A Legal and Economic Analysis of the Proposed Modernization of the Enforcement of EC Competition Law', (2002) 9 Columbia Journal of European Law 1. 
procedures. NCAs are obliged to notify the European Commission when they initiate proceedings, and the Commission may take cases with broad Community scope away from individual NCAs by starting its own proceedings. Conversely, the European Commission is obliged to consult an Advisory Committee on Restrictive Practices and Dominant Positions, composed of NCA representatives, before taking decisions, to take 'utmost account' of its advice, and to inform the Committee of its response. The Advisory Committee's opinions may be published, subject to commercial confidentiality considerations. To complete the circle, European Commission is also empowered to make oral or written submissions to national courts 'at its own initiative and in the Community public interest'.

Among the benefits of the new system of networked competition regulation in the eyes of the European Commission are the opportunities it offers to exploit the superior local knowledge of NCAs and national courts through experimentation and benchmarking: 'multiple enforcement is likely to lead to more innovation in the interpretation and application of the law. Enforcement by several authorities is likely to be more creative, innovative and adaptive to change than enforcement by a monopolist authority' ${ }^{82}$ But according to Geradin, this experimentalist potential of the new regulatory framework may be limited by its continuing commitment to a a rather 'top down' vision whereby there would be many competition law enforcing authorities, but essentially one authority in charge of competition policy, the European Commission. The European Commission's competition policy vision would be conveyed through a variety of instruments, such as guidelines, comments on draft decisions from national authorities, the submission of written or oral observations to courts, etc. Though it can to some extent be justified by the need to maintain a coherent application of EC competition rules, such a top down vision would inevitably reduce the degree of experimentation at least at the level of policy orientations. However, some innovation space would be maintained at the level of their translation into practical decisions. ${ }^{83}$

\section{State Aid}

A similar networked governance approach has been suggested for reform of the EU's state aid regime, which closely resembles competition policy before the 2003-2004 Modernisation Package. National state aid to industry is illegal in general, with a series of exemptions/derogations for purposes specified in the Treaty. The European Commission has a monopoly of enforcement in the field, subject to review of its decisions by the ECJ, and all state aid must be notified to the Commission for review of its legality. Until very recently, there was little formal legislation in this field, and the European Commission relied mainly on issuance of 'soft law' guidelines to shape Member State behaviour, underpinned by its own legally binding decisions in disputed cases. In response to the Court of First Instance's growing insistence on provision of detailed

${ }^{82}$ Wouter Wils, Commission Legal Services, quoted in ibid, at 20.

83 ibid, at 20; cf also S. Wilks, 'Agency Escape: Decentralization or Dominance of the European Commission in the Modernization of Competition Policy?' (2005) 18 Governance 431. According to O. Budzinski and A. Christiansen, 'Competence Allocation in the EU Competition Policy System as an Interest-Driven Process', (2005) 3 Journal of Public Policy 313, at 324-325, who share similar concerns about the centralising potential of the new arrangements, national competition authorities so far seem surprisingly satisfied with their operation, from which they infer that 'to date the Commission could avoid the impression of a too obvious dominance so that mutual cooperation and exchange appears to be possible'. 
information to justify state aid decisions, the European Commission proposed and the Council passed two new regulations at the end of the 1990s. The first (1998) gives the European Commission authority to exempt entire categories of aid from the notification requirements, ie to issue its own regulations subject to limits set by the Council. The second (1999) codifies the decision-making procedures applicable in the field of state aid, imposing greater transparency and stricter time limits in return for reduced risk of intervention in the process by national and European courts. As in the case of antitrust policy, a key problem is the overburdening of the European Commission by review of routine cases resulting from the centralised notification procedure. So far, however, no comparable decentralisation has been introduced. ${ }^{84}$

As part of its 2005 State Aid Action Plan, the European Commission is now considering the creation of a network of independent authorities in the Member States, which would share responsibility for enforcement of Community rules in terms of detection and recovery of illegal aid, while also facilitating the horizontal flow of information and exchange of best practices. This approach would build explicitly on the experience of national monitoring authorities established in the new Member States as part of the enlargement process, which the European Commission considers to have been extremely effective in screening and curbing illegitimate state aid. The European Commission also plans to encourage Member States, in partnership with national Courts of Auditors, to engage in benchmarking exercises 'to verify that state aid is achieving the objective and is the best type of state intervention for any given objective'. Finally, the European Commission aims to enlist the assistance of national courts and other bodies in monitoring whether measures deemed to fall under liberalised block exemption and minimum thresholds, which do not require centralised notification, 'actually fulfil the necessary criteria'. ${ }^{85}$

\section{From Rules to Rights}

A final extension of the experimentalist architecture concerns its application not to new domains of regulation, but rather to the determination of fundamental rights. The backdrop of this development is the widely noted explosive proliferation of justiciable human or fundamental rights in the EU. For this proliferation there are at least three convergent causes. From above, the international community has exerted pressure on the EU to acknowledge and incorporate into its law the large body of human rights law elaborated in various global fora. Pressure to adopt fundamental rights has also come from below, from the Member States. In many of these, traditional beneficiaries of social solidarity, such as the disabled, have increasingly insisted that their needs be accommodated as a matter of right, not of public generosity, which they take in even its most beneficent forms to be stigmatising and exclusionary. Reinforcing the pressures from above and below has come a horizontal pressure from old and recently admitted Member States on one another to safeguard through the provision of rights and

${ }^{84}$ M. Cini, 'The Soft Law Approach: Commission Rule-Making in the EU's State Aid Regime', (2001) 8 Journal of European Public Policy 192; P. Nicolaides, 'Decentralised State Aid Control in an Enlarged European Union: Feasible, Necessary or Both?', (2003) 26 World Competition Law \& Economics Review 263.

${ }^{85}$ European Commission, State Aid Action Plan. Less and Better Targeted State Aid: A Roadmap for State Aid Reform 2005-9, COM (2005) 107 final, Brussels, 7 June, especially paras 48-56; for an earlier proposal along similar lines, see Nicolaides, op cit $\mathrm{n} 84$ supra. 
corresponding institutions the democratic acquis of the EU and to protect it against possible outbreaks of xenophobia. ${ }^{86}$

\section{Experimentalist Rights: The Race Discrimination and Equal Treatment Directives}

But for present purposes, we are concerned not with the origins of these rights, but rather with the way in which their application and ultimate meaning is being shaped by the same recursive processes at the heart of the experimentalist regulation. Consider as a key example the EU anti-discrimination measures adopted in 2000. These consist of two framework directives and an 'action programme' to combat discrimination. The Race Discrimination Directive addresses ethnic and racial discrimination in a wide range of social and economic settings; ${ }^{87}$ the Directive on Equal Treatment in Employment and Occupation addresses discrimination in a particular setting - at the workplace and in employment relations - on a wide range of grounds, including sexual orientation, age, disability, ethnicity, and religious belief..$^{88}$ In unequivocally prohibiting discrimination the Directives are in the spirit of traditional human (and civil) rights. The categorical prohibition on discrimination - a practice or decision that disadvantages an individual or group relative to others solely on grounds judged irrelevant to relations among equal citizens - is effective precisely because its unequivocal textual requirements are easily intelligible to courts. In establishing equality of treatment of potentially disadvantaged groups as an open-ended goal, however, the Directives are establishing a distinct and novel kind of right in the spirit of the framework regulation characteristic of EU governance. In the case of persons with disabilities, for instance, a rule permitting employers to consider in hiring only those attributes of job applicants directly relevant to their prospective employment prohibits many kinds of discrimination, yet does not protect persons with disabilities that could affect performance. Anticipating this difficulty the Equal Treatment Directive obligates employers to provide 'reasonable accommodation' to persons with disabilities, where 'reasonable' depends on the accommodations actually afforded in the practice of various national administrations.

But this apparent distinction between a traditionally justiciable, textually unambiguous prohibition on discrimination and an open-ended requirement of equality (vindicated through framework rules) proves in practice untenable, even in what might seem its natural habitat of anti-discrimination rules. The ambiguities of addressing discrimination against pregnant women show why. Gender-blind rules or practices that penalise the career disruptions associated with child bearing discriminate against pregnant women even if they nowhere announce or even intend this. So a bright-line rule requiring gender-blind interpretations is obviously useless in these circumstances. Indeed, the only general way to address, rather than aggravate, this and many other kinds of discrimination is to convert them into questions of accommodation: to require, for instance, that differences in physiology between the sexes be accommodated so that

\footnotetext{
86 These pressures have been amplified by an emergent alliance between the Commission and European NGO networks, each pursuing their own intersecting interests in Europeanising anti-discrimination policies: see T.F. Burke, 'The European Union and the Diffusion of Disability Rights', in M.A. Levin and M. Shapiro (eds), Transatlantic Policymaking in an Age of Austerity (Georgetown University Press, 2004).

${ }^{87}$ Council Directive 2000/43/EC of 29 June 2000 implementing the principle of equal treatment between persons irrespective of racial or ethnic origin, [2000] OJ L 180/0022.

${ }^{88}$ Council Directive 2000/78/EC of 27 November 2000 establishing a general framework for equal treatment in employment and occupation, [2000] OJ L 303/16.
} 
men and women have equal chances to advance precisely because these differences are openly acknowledged, not ignored. By this route the prohibitions of discrimination come to resemble the requirement of reasonable accommodations needed to secure equality, and to raise with the latter the problem of defining a standard or comparison group - a comparator - with reference to which the reasonableness of any particular accommodation can be judged. Bright-line rules of doctrine give way to investigation of open-ended, rapidly evolving social possibility.

Courts alone, it is widely acknowledged, have a poor record of giving current and corrigible meaning to requirements of this kind, ${ }^{89}$ or to the far more encompassing goal of the Race Directive to implement 'the principle of equal treatment between persons irrespective of racial or ethnic origin'. ${ }^{90}$ But peer review of implementation efforts by relevant authorities and civil society actors - and subject to judicial scrutiny - may, at least in some circumstances, be better suited to making effective sense of such openended goals - a more suitable forum of principle than courts alone. Here is where the action programme to combat discrimination comes in. Its aim is to increase the capacity of national administrations, EU bodies, networks of experts and NGOs at the national and EU levels to assess and propose reforms of the rapidly evolving law and practice of ending discrimination and promoting equality of treatment. Linked together in forms that are already familiar from the regulatory realm of EU governance, these newly capacitated actors could, as one close observer of both EU law and human rights suggests, extend the system of peer review from regulation to rights. ${ }^{91}$

\section{Monitoring Fundamental Rights: Article 7, the Expert Network, and the New Fundamental Rights Agency}

The creation of an EU Fundamental Rights Agency (scheduled to begin operations in 2007) formalises and generalises this synthesis. In response to the populist electoral successes of Jörg Haider in Austria in the late 1990s, and the fears of widespread xenophobia that they aroused, the Treaty of Nice granted the EU Council, in Article 7 of the Union Treaty, the authority to sanction Member States for persistently breaching the common values on which the EU is founded, including human rights. ${ }^{92}$ But just as the determination of a 'reasonable' accommodation 'reasonable' depends in part on the accommodations actually afforded, so the non-arbitrary determination of persistent breaches of rights depends on a (continually corrected) baseline of practices in Member States of identifying and sanctioning rights abuses. As two leading protagonists in the construction of the new institutions put it:

In order to ensure that such a mechanism [of sanctions] is used in a non-selective manner, it should proceed on the basis of a systematic monitoring by independent experts, providing comparable

${ }^{89}$ For a canvass of classic and recent objections, together with the claim that contemporary court practice, in the US at least, is responding effectively to them, see Sabel and Simon, op cit n 10 supra.

${ }^{90}$ Council Directive 2000/43/EC of 29 June 2000, op cit n 90 supra, recital 14.

${ }^{1}$ G. de Búrca, 'EU Race Discrimination Law: A Hybrid Model', in G. de Búrca and J. Scott (eds), Law and New Governance in the EU and the US (Hart, 2006).

92 The following is based on P. Alston and O. De Schutter, 'Introduction: Addressing the Challenges Confronting the EU Fundamental Rights Agency', in P. Alston and O. De Schutter (eds), Monitoring Fundamental Rights in the EU: The Contribution of the Fundamental Rights Agency (Hart, 2005); O. De Schutter, 'Mainstreaming Human Rights in the European Union', in ibid; and G. de Búrca, 'Beyond the Charter: How Enlargement Has Enlarged the Human Rights Policy of the EU', in O. De Schutter and S. Deakin (eds), Social Rights and Market Forces: Is the Open Coordination of Employment and Social Policies the Future of Social Europe? (Bruylant, 2005). 
data and objective assessments on the situation of fundamental rights in all the Member States of the Union. ${ }^{93}$

To this end an EU Network of Independent Experts on Fundamental Rights was created to 'detect fundamental rights anomalies or situations where there might be breaches or the risk of breaches of these rights falling within Article 7 of the Union Treaty', and to 'help in finding solutions to remedy confirmed anomalies or to prevent potential breaches'. If, as seems likely, this network becomes the core of the Fundamental Rights Agency, then peer review of fundamental rights will have been in some important measure officialised in the EU. ${ }^{94}$

But these developments raise a particular worry with a potentially general implication. With regard to rights, the worry is that an open-ended formulation can make them hostage to shifting social preferences - putting them, that is, at the mercy of just the kinds of utilitarian calculations that the commitment of values to rights is meant to forestall. The broader worry is that this potential concern for rights just makes manifest a deep flaw inherent in experimentalist governance more generally: in rendering rule making more flexible and responsive to contextual differences and changing circumstance, could it not be that this new architecture puts at risk the accountability of government to the governed and even the rule of law itself? To show why these concerns are misplaced, we explain in the next section how peer review can afford accountability when the principal-agent relation on which we normally rely for this cannot, and further how such peer review can give rise to binding obligations that go far beyond the monitory exhortations of 'soft law' without depending on the hierarchical capacities of the traditional centralised state.

\section{The Theory and Practice of Framework Revision}

\section{A From Principal-Agent Governance to Peer Review and Dynamic Accountability}

Accountability in representative democracy follows the principal-agent model. The democratic sovereign sitting in the legislature sets goals and delegates responsibility for their execution to the administrative branch. The legislature periodically reviews the administration's fidelity to statutory instruction and the electorate periodically judges the legislature's fidelity to its political mandate. Constitutional courts in both Europe

93 Alston and De Schutter, ibid, at 7.

94 The questions of whether the new Fundamental Rights Agency should continue the practice initiated by the network of independent experts of issuing regular monitoring reports on the situation of fundamental rights in individual Member States, rather than responding only to 'clear and persistent breaches' of Article 7, and whether the Agency's remit should extend to acts of Member States outside the field of application of EU law, remain controversial. For an extended analysis by the Coordinator of the Network of Independent Experts, which also proposes the integration of ongoing monitoring into an OMC to facilitate mutual learning between EU Member States in ensuring and improving the protection of fundamental rights within the EU, see O. De Schutter, Monitoring Fundamental Rights in the Union as a Learning Process, unpublished paper presented to the Seminar on Fundamental Rights and Reflexive Governance, Columbia Law School, New York, 4 November 2005. For a critical discussion of this and other proposals to apply the OMC to fundamental rights, see K. Armstrong, The Open Method of Co-ordination and Fundamental Rights: A Critical Appraisal, unpublished paper presented to the Seminar on Fundamental Rights and Reflexive Governance, Columbia Law School, New York, 4 November 2005 . 
and the USA vigorously assert the primacy of the politically accountable principal over its administrative agent and require therefore that the delegation of authority from the former to the latter be limited and controlled by the definition of legislative goals. ${ }^{95}$

The difficulty, of course, and the open secret of administrative law in both the EU and the USA, is that it is very often-regularly? - the case that no actor among those seeking to coordinate their efforts has a precise enough idea of the goal either to give precise instructions to the others or reliably recognise when their actions do or don't serve the specified end. So long as at least one actor can indeed survey the space of possible solutions with the precision required by this condition, principal-agent relations are possible, though it turns out to be trickier than one might think to identify who is the principal and who the agent. But if solutions can only be identified as they are pursued - if, in other words, actors have to learn what problem they are solving, and what solution they are seeking, through the very process of problem solving - then principal-agent relations are impossible, not least because the very distinction between principal and agent is confounded. The recursive redefinition of means and ends that we have seen to be at the heart of the experimentalist architecture of EU governance acknowledges and responds to precisely this situation. More yet: so much rule making in national and global fora occurs under such circumstances-beyond the ken of the 'command and control' relations characteristic of the modern state - that administrative lawyers have begun to speak of the production of 'anomalous' administrative law. ${ }^{96}$ The question - raised most urgently by the extension of this architecture to rights, but insistently in regulatory domains as well - is whether it is possible to establish some form of accountability in such a fluid situation: whether 'anomalous' administrative law can be accountable. For present purposes, and staying within the bounds of this essay, we can conveniently show that there is by tracking some recent work on the EU that 'discovers' a model of administration providing accountability even in the absence of a clear specification of initial goals.

This discovery process is cogently modelled in Nicolaides et al's work on policy implementation in the EU. Their initial aim is simply to apply the tested and true principal-agent framework to the ramshackle structure of the EU. But from this point of view, two oddities need to be taken into account. The first is that the principal, the EU, has multiple agents, the national administrative authorities. Agents being what they are, each of these will interpret the principal's instructions - a directive, say - in a self-serving way; and the principal will of course be determined to minimise this agency 'drift'. The second, empirically motivated oddity is that the principal is presumed to have only a vague or provisional idea of its own goals. Thus sometimes self-interested drifting by national administrative agencies will reveal possibilities that the principal has overlooked, and prefers more than any of the options entertained ex ante. In other words, the principal can sometimes learn from the agents. Since accountability cannot under this circumstances be established by comparing rule to performance - the performance is going to change the rule - how can it be achieved? The device is simple:

Accountability is strengthened not when the actions of the agent are constrained but when the agent is required to explain and justify his actions to those who have the necessary knowledge to understand

95 The key decisions are Cases 21-26/61, Meroni v High Authority [1962] ECR 73 in the EU, and Chevron USA, Inc v Natural Resources Defense Council, Inc, 467 US 837 (1984) in the US.

96 B. Kingsbury, N. Krisch, and R.B. Stewart, 'The Emergence of Global Administrative Law', (2005) 68 Law and Contemporary Problems 15; J. Cohen and C.F. Sabel, 'Global Democracy?', (2006) 37 NYU Journal of International Law and Politics 763. 
evaluate those actions. We conclude, therefore, that effective delegation must confer decision-making discretion to the agent, while effective accountability mechanisms must remove arbitrariness from the agent's actions by requiring him to (a) show how he has taken into account the impact of his decisions on others, (b) explain sufficiently his decisions and (c) be liable to judicial challenge and, preferably, to some kind of periodic peer review. The latter is very important because only peers have the same knowledge to evaluate the agent's explanations. ${ }^{97}$

Accountable behaviour in this setting no longer is a matter of compliance with a rule set down by the principal, as if the principal knew what needed to be done, but rather provision of a good explanation for choosing, in the light of fresh knowledge, one way of advancing a common, albeit somewhat indeterminate project (as all projects are). At the limit principal-agent accountability gives way to peer review through fora, networked agencies, councils of regulators, and OMCs: the full repertoire of processes by which EU decision makers learn from and correct each other even as they set goals and performance standards for the Union. Peer review becomes in turn dynamic accountability - accountability that anticipates the transformation of rules in use - and dynamic accountability becomes the key to 'anomalous' administrative law: the exceptional kind of administrative law that must become the rule when administration is not built on a 'core of command-and-control', and cannot be because it does not operate in the state's shadow. Accountability generically understood means presenting the account of one's choices that is owed to others in comparable situations. Here then is a form of accountability that does not require a central, delegating authority. Elsewhere, we have argued that the deliberative polyarchy sketched above embodies this ideal of dynamic accountability; ${ }^{98}$ and we examine through two case studies later in this section how such accountability develops within and reshapes EU administration. First, however, we need to set peer review in relation to other institutions of governance that enable its operation and ensure the effectiveness of its outcomes.

\section{B Experimentalist Governance: Neither 'Soft Law' Nor Rule Making in the 'Shadow of Hierarchy'}

In isolation peer review can be ineffective, indeed unworkable: ineffective because its deliberations might seem to yield only recommendations that can be ignored without penalty by those to whom they are addressed; unworkable because in the absence of any sanction or discipline the actors could well choose to limit themselves to pro forma participation or worse yet manipulate the information they provide so as to show themselves, deceptively, to best advantage. For these reasons, it is has often been argued that the new governance mechanisms of the EU can result merely in the admonishments of 'soft law' that achieve the very modest effects of which they may be capable only because some actors can sometimes be moved by moral suasion or the baser fear of public embarrassment. ${ }^{99}$

But in the event peer-review accountability is not bereft of means to induce participation in its processes or respect for its outcomes. Chief among these is what we call the

${ }^{97}$ Nicolaides et al, op cit n 16 supra, at 46.

98 Cohen and Sabel (1997), op cit $\mathrm{n} 9$ supra; Gerstenberg and Sabel, op cit $\mathrm{n} 9$ supra; Cohen and Sabel (2003), op cit $\mathrm{n} 9$ supra.

99 For a discussion of this 'soft law' debate in relation to the OMC, see D.M. Trubek and L.G. Trubek, 'The Open Method of Co-ordination and the Debate over "Hard" and "Soft" Law', in Zeitlin and Pochet, op cit $\mathrm{n} 54$ supra. 
penalty default. As first introduced by Ian Ayres and Robert Gertner, ${ }^{100}$ the idea draws attention to deficiencies in the standard, contract-law understanding of a default rule (the rule courts apply when the agreement lacks a relevant provision) as the rule the majority of contracting parties would have agreed on had they bargained over the issue. Ayres and Gertner pointed out that such rules will be unjust or inefficient in a significant range of cases where there are asymmetries of information. Default rules that would not be chosen by a majority of parties may nevertheless be desirable, if they can be cheaply contracted out of by those who do not want them, because they will induce the disclosure of information that would otherwise be withheld. A default rule that says that sellers are liable only for foreseeable consequences of a breach is better than one that provides liability for all harm incurred by the buyer, even if most sellers would ultimately agree to the unlimited damage rule. The foreseeability rule is better because it gives the buyer an incentive to inform the seller of any unusual risks non-performance presents, and such disclosure in turn encourages the parties to bargain in an informed fashion to their own rule. In formulating a penalty default, the rule-maker does not try to approximate the optimum outcome. Rather, it tries to create incentives for the parties to produce a rule that approximates the optimum outcome.

The idea of a penalty default can be extended from one-shot transactions to ongoing regimes where sequences of rules have to be written when information is asymmetrically distributed, inaccessible to outsiders, and so incomplete and rapidly changing as to be highly unreliable for even the momentarily best informed party. These are the very circumstances in which principal-agent accountability breaks down because no actor has reliable knowledge of what to do. Under these conditions a court or administrative agency imposes a penalty default on the actors if they do not establish a system for warranting to one another the information they disclose, and then acting on what they currently know to regulate their interdependence fairly and efficiently. Such a penalty default typically takes the form of a rule that everyone fears more than forms of mutual accommodation that no party might independently choose. ${ }^{101}$

A further generalisation of the penalty default concept is the idea of a destabilisation regime, where there is a cumulation of features that can be marshalled to make the current situation for incumbents untenable. These regimes do as much to wean actors from previously unquestioned commitments by suggesting plausible and superior alternatives as by in effect terrorising them into undertaking a search for novel solutions. Some developments in the EU approximate the information-forcing penalty default mechanism, but the broader destabilisation or disentrenching regime seems to be more common.

The Florence Electricity Forum provides a notable example of the use of the penalty default in the EU. ${ }^{102}$ To unblock potential impasses in the deliberative process, the European Commission has periodically threatened to invoke its formal powers under

100 I. Ayres and R. Gertner, 'Filling in the Gaps in Incomplete Contracts: An Economic Theory of Default Rules', (1989) 99 Yale Law Journal 87.

101 B. Karkkainen, 'Information-Forcing Regulation: Penalty Defaults, Destabilization Rights, and New Environmental Governance', in de Búrca and Scott, op cit n 91 supra.

102 Other well-attested examples of penalty default mechanisms in EU regulation include the 1991 Software Directive, the 1994 European Works Council Directive, and the 2006 Registration, Evaluation, and Authorisation of Chemicals (REACH) Regulation: see I. Ayres, 'Ya-Huh: There Are and Should Be Penalty Defaults', (2006) 33 Florida State University Law Review, 589, at 605; C. Barnard and S. Deakin, In Search of Coherence: Social Policy, the Single Market and Fundamental Rights', (2000) 31 Industrial Relations Journal 331, at 342; J.S. Applegate and K. Baer, 'Strategies for Closing the Chemical Data 
EU antitrust, merger control and state aid rules. Thus as Eberlein observes, 'Forum actors are reminded that obstruction or intransigence can be addressed under competition law - the application of which may make the intransigent or obstructionist parties worse off than a compromise reached in the Forum'. ${ }^{103}$ As in many other areas of EU policy making, moreover, the European Commission's powers of legislative initiative and delegated regulation have also served as a means of inducing Member State and private actors to cooperate in framework rule making within the Florence Forum. This mechanism has proved especially effective in the case of thorny issues such as cross-border tarification where the parties fear the unpredictable consequences of an imposed alternative. The experience of the Florence Forum is a striking, but hardly unique example of how the EU's institutions work together to create a broader destabilisation regime. ${ }^{104}$

In sum the new destabilisation regime-whether or not accompanied by penalty default in the strict sense-shifts the regulatory focus from rules to frameworks for creating rules. This shift is of a piece with, and helps establish the background conditions for, the shift from accountability as rule following to accountability as the justifiable exercise of discretion subject to peer review.

But in steering clear of the Scylla of a trivialising soft-law interpretation of the new architecture, it might seem that we will run aground on the Charybdis of an interpretation contrary to this first, except insofar as it diminishes the novelty and significance of what we take to be the key innovation in EU governance: the view of the new architecture as operating in the 'shadow' of traditional public hierarchy. This 'shadow of hierarchy' view extends to EU governance a trope originally developed to explain collective bargaining and neo-corporatist concertation between the state, labour and capital. The core idea is that the state or public hierarchy more generally is limitedperhaps because of the volatility of the situation in which it acts - in its ability to secure the outcomes that it prefers, or would prefer if it could identify them in advance. Given this limitation, the state enlists non-state actors who do command the necessary capacities in its problem solving by proposing an exchange: in return for their promise to bargain with one another fairly and in a public-regarding way, the relevant parties are endowed with a semi-constitutional authority to speak on behalf of their members and the assurance that their agreements will be backed by the authority of the state, provided only that they respect the conditions of the founding bargain itself. Parties to such agreements are thus reasonably said to be 'bargaining in the shadow of the state' and acting in some sense as its authorised agents or deputies in reaching solutions not directly available to the authorities themselves. ${ }^{105}$ Seen this way, the new architecture that we describe might be thought to be simply a capacity-increasing extension of the EU's formal hierarchical decision-making apparatus rather than a networked,

Gap', Center for Progressive Reform White Paper No 602, April 2006, available at http://www. progressivereform.org/articles/Closing_Data_Gaps_602.pdf, at 9 (accessed 14 July 2007).

103 Eberlein (2005), op cit $\mathrm{n} 20$ supra, at 80.

104 Other examples of destabilisation or disentrenching mechanisms in EU governance comprehend the devices whereby Member States' attention — not to say fear-is directed to the cascading externalities provoked by inaction in the face of or uncoordinated response to change. These include Member States' fear of the possible costs of inaction on matters of common concern (eg the non-police of borders or the burdens of uncoordinated asylum policies), and relevant decisions of the European courts, as well as the endogenous operations of peer review and other evaluation procedures themselves.

105 F.W. Scharpf, Games Real Actors Play: Actor-Centered Institutionalism in Policy Research (Westview Press, 1997), at 197-205. 
deliberative alternative to it. At the limit, this argument simply applies to governance an idea familiar from organisational sociology, in which the capacities of a rigid formal organisation are rendered flexible by connecting it to an informal network over which the official hierarchy maintains control. ${ }^{106}$

But while destabilisation regimes as inducements to explore novel possibilities and to respect the outcome of informed deliberation draw on official authority, they do so in a way that is crucially different from the use of state power that occurs in the shadow of hierarchy. In the latter, the authorities acting independently could arrive at an (almost) acceptable disposition of the problems before them, though this unilateral determination could be substantially improved by the participation of the better informed non-state actors. As Héritier, a leading proponent of the 'shadow of hierarchy' view of the EU's new governance architecture, puts it: 'should there be mismanagement or policy failure, public authorities may take on the regulatory functions' ${ }^{107}$ Indeed, these non-state actors are motivated to participate in decision making precisely because they can calculate what they will gain by bargaining in the shadow of hierarchy over the alternative outcome that would be imposed by the authorities themselves. ${ }^{108}$

By contrast, in a destabilisation regime with peer review, the best 'solution' available to authorities acting themselves is so manifestly unworkable to the parties as to count as a draconian penalty and an incalculably costly disruption of their capacities to control their own fate. Indeed, it is precisely the patent unworkability of official solutions - the failures, if you like, of rules made by anything like traditional meanswhich makes the mere threat of imposing them so effective a device for inducing the parties to deliberate in good faith. To return to the example of the Florence Electricity Forum, the penalty defaults at work here cannot be considered viable hierarchical substitutes for recursive rule making through networked, experimentalist governance, as Eberlein (who is himself attracted to the idea of the 'shadow of hierarchy') clearly shows. Thus competition law, 'based as it is on ex post and case-by-case procedures, is a negative control instrument', which cannot produce the kind of 'fine-tuned' regulatory solutions developed by the Forum. Similarly:

further legislation, even if more stringent and detailed, will still need to be interpreted and implemented on the national level. And legislation, by its very nature, cannot address all current and future regulatory needs in a technically complex, evolving policy area. It will leave regulatory gaps. Hence the need for detailed rule development and coordination on a transnational basis will persist. ${ }^{109}$

106 Christiansen and Piattoni, op cit $\mathrm{n} 3$ supra; Eberlein and Grande, op cit $\mathrm{n} 3$ supra.

107 A. Héritier, 'New Modes of Governance in Europe: Policy-Making without Legislating?', in A. Héritier (ed), Common Goods: Reinventing European and International Governance (Rowman \& Littlefield, 2002), at 194.

108 The EU Social Dialogue procedure, whereby representative associations of business and labour are empowered to negotiate European framework agreements which can be transformed into legally binding directives, is a clear example of this dynamic. Only when the Council and the Parliament are prepared to legislate, and the Social Partners calculate that they can craft a mutually more advantageous deal between themselves, can such legally binding agreements be concluded - conditions which have been satisfied just three times at an interprofessional level and three times at a sectoral level since the procedure was introduced by the Maastricht Treaty in 1992: see G. Falkner, EU Social Policy in the 1990s: Towards a Corporatist Policy Community (Routledge, 1998); A. Héritier, 'New Modes of Governance in Europe: Increasing Political Capacity and Policy Effectiveness?' in T. Börzel and R. Chichowski (eds), The State of the European Union, vol 6: Law, Politics, and Society (Oxford University Press, 2003); Obradovic, op cit n 55 supra.

109 Eberlein (2005), op cit n 20 supra, at 80-81. Following Eberlein, Héritier (2003), ibid, interprets the success of the Florence Electricity Forum, as a case of 'regulatory cooperation in the shadow of hierarchy'. But 
Hence bargaining under these conditions is not bargaining in the shadow of hierarchy, but rather deliberating when hierarchy has itself become a shadow: powerful not for what it can deliver, but only for what it can obscure and disrupt. In short, the new architecture of EU governance is not 'soft law', but neither is it traditional 'hard law' of a form that grows out of and is reducible to principal-agent rule making. With these prefatory clarifications, we turn now to case studies of dynamic accountability to illustrate how in the context of a destabilisation regime the actors devise procedures for making formal but revisable rules.

\section{Dynamic Accountability in Action}

1 Self-Revising Regulation by Design: The Water Framework Directive and Its Common Implementation Strategy

The Water Framework Directive (WFD) was adopted in 2000 after years of intense negotiation between the European Commission, the Council, and the Parliament, involving extensive participation by both industrial interest groups and environmental NGOs. It replaces seven detailed 'first wave' directives from the 1970s (covering sectors such as dangerous substances, surface water, fish water, etc) with a single broad, integrative and open-ended regulatory framework. ${ }^{110}$ The WFD aims to improve water quality and ensure sustainability of water resources across the EU through integrated management of river basins, while requiring Member States to achieve 'good status of water quality' by 2015. The concept of 'good water status', which includes ecological as well as chemical dimensions, is explicitly open-ended, with the methods, tools, metrics, and values for its assessment to be developed through the implementation process. The directive establishes three routes for its implementation, which in practice have become closely intertwined: a legislative route, through the adoption of European 'daughter' directives (eg on groundwater protection); an executive route, through the European Commission's power to issue decisions and guidelines subject to a comitology procedure; and a Member State route, through autonomous action by national authorities. ${ }^{111}$

Central to the practical implementation of the WFD, however, has been a new institution not formally envisaged in the directive itself: the Common Implementation Strategy (CIS), an 'informal' forum for 'open cooperation' and information sharing created in May 2001. Conceived by the EU Water Directors (national representatives responsible for water policy, usually division heads within environmental ministries) and agreed by the European Commission, the CIS aims at helping Member States to implement the WFD and avoid regulatory conflicts arising from incompatible implementation practices The CIS operates through three nested levels of organisation:

such an interpretation is misconceived, because in contrast to the classic examples of 'bargaining in the shadow of the state', the EU authorities are unable to take over the regulatory functions in question themselves should networked deliberation fail.

${ }^{110}$ M. Kaika, 'The Water Framework Directive: A New Directive for a Changing Social, Political and Economic European Framework', (2003) 11 European Planning Studies 299; A. Weale, G. Pridham, M. Cini, D. Konstadakopulos, M. Porter and B. Flynn, Environmental Governance in Europe (Oxford University Press, 2000), at 359; A. Lenschow, EU Environmental Governance: An Assessment of Its Newness, unpublished paper presented to the EUSA 9th Biennial International Conference, Austin, Texas, 31 March-2 April 2005, at 10.

111 J. Scott and J. Holder, 'Law and "New" Environmental Governance in the European Union', in de Búrca and Scott, op cit $\mathrm{n} 91$ supra. 
working groups charged with technical consultation and preparation of non-binding guidance documents; a Strategic Coordination Group (SCG) chaired by European Commission with Member State representatives, responsible for reviewing the working groups' activities and advising the Water Directors; and biannual meetings of Water Directors, co-chaired by European Commission and Council Presidency, responsible for steering the process as a whole. ${ }^{112}$

The primary outputs of the CIS are non-binding technical guidance documents, such as indicators and values for measuring water quality and defining 'good' water status. These are supposed to be 'developed in a pragmatic way based on existing practices in Member States', embodying best available knowledge, and are conceived as 'living documents' subject to ongoing review and updating. But Member States are also obliged to submit regular reports to the European Commission on the implementation of the WFD, including both water management plans and programs for monitoring water status. The European Commission in turn produces its own regular implementation progress reports, including reviews of EU water status, surveys of Member State water management plans, and proposals for future improvement, all of which draw on scoreboards based on benchmarks developed through the CIS. ${ }^{113}$

Not only the outputs of the CIS, but also its organisational arrangements are 'regarded as provisional and subject to revision in the light of experience'. Regular biennial reviews have resulted in the establishment of a revised structure designed to ensure better integration among implementation activities by streamlining work and addressing cross-cutting issues more effectively. The review process has also led to the creation of new steering, drafting, and expert groups for the preparation of guidance documents under the supervision of the SCG, an arrangement aimed at balancing devolution of tasks to small, efficient units with transparency and accountability to the wider implementation network. ${ }^{114}$

CIS activities more generally feed both directly and indirectly into revisions of the WFD. Thus legislative proposals for new daughter directives are developed in a spirit of open consultation' through multi-stakeholder Expert Advisory Fora modelled on CIS working groups, with representatives from NGOs, industry associations, and outside experts, as well as from national authorities and the European Commission. Once established, some of these expert fora have then been transformed into CIS working groups, in order to achieve a better integration between reviews of ongoing implementation and proposals for new policy development. CIS guidance documents may also be given legally binding status by the European Commission and Member State representatives under comitology procedures, as in the case of national implementation reporting. ${ }^{115}$

\section{Overcoming Blockages through Reflexive Reform: Environmental Impact Assessment}

If the WFD and its CIS shows how EU institutions for the recursive revision of institutional arrangements in the light of experience produce revisions when those

112 ibid; I. von Homeyer, Horizontal Co-ordination of Policies and Application of the OMC in EU Environmental Policy, presentation to the conference on Options for the OMC in European Spatial Development, German Federal Office for Building and Regional Planning, Bonn, 2 September 2005.

113 Scott and Holder, op cit n 111 supra, at 229-231.

114 ibid, at 231-233.

115 ibid, at 237. 
institutions are working well, the Environmental Impact Assessment (EIA) Directives show instead how these revisionary institutions can themselves be revised to overcome blockages. The original directive dates back to 1985, and requires Member States to establish EIA procedures to ensure that environmental considerations are taken into account in the authorisation of proposed projects. The EIA directive establishes framework rules which give Member States considerable flexibility in implementation, buttressed by provisions for derogations and opt-outs. But such national autonomy is subject to procedural safeguards aimed at ensuring accountability in implementation. One set of safeguards concerns information sharing and reporting: Member States and the European Commission are required to share information on implementation experience; Member States are required to inform the Commission of their criteria and thresholds for projects to be assessed; and the Commission is required to issue regular reports on the directive's implementation. A second set of procedural safeguards concerns transparency and participation: Member States are required to ensure that applications for development consent are available to the public, and to establish rules for public participation in EIA.

The effectiveness of EU EIA is highly controversial, both in principle (can such procedural requirements really improve substantive outcomes?) and in practice (are the Directive's requirements respected?). Thus Andrea Lenschow observes that 'The EIA directive is one [of] the worst implemented pieces of environmental legislation and assessments already at the stage of policy formulation are widely resisted'. ${ }^{116}$ But Scott and Holder argue that such dismissive judgements miss the mark both theoretically and empirically, failing to understand the mechanisms through which EIA can influence decision making and ignoring recent evidence of its influence in this direction.

[T] he requirement that the decision maker evaluate various options or alternatives to the proposed project or policy ... provides a degree of anticipatory control because environmental harm may be prevented or reduced by identifying possible alternative sites, designs, or technology at an early stage in the consent process. There is some evidence that this requirement has proved to be a forceful one, at least in the context of environmental assessment procedures invoked in cases of nature conservation. ... There are ... recent signs that environmental assessment is capable of swaying decision making away from certain development projects. ${ }^{117}$

Not only has EIA proved more effective than its critics charge, but the Directive has been 'repeatedly reviewed and revised' to overcome weaknesses in its implementation. Such revisions, moreover, have been generated by review processes built in to the Directive itself, which 'provides the tools for iterative evaluation and adaptation'. Thus the European Commission is obliged to produce regular quinquennial reports on the implementation of the EIA Directive, based on Member State reporting, questionnaires, and consultancy research. On the basis of these reports, the European Commission prepares detailed 'guidance notes' for improving Member State implementation, seeking to diffuse 'best practices' which go beyond legal requirements; advances amendments to the existing Directive, and develops proposals for new legislation. In addition, ECJ decisions have narrowed the flexibility allowed to Member States in certain areas to ensure the conformity of their procedures with the Directive's underlying objectives. Thus Member States are prohibited from exempting whole classes of project in advance (unless they are unlikely to have significant environmental

\footnotetext{
116 Lenschow, op cit n 110 supra, at 12.

117 Scott and Holder, op cit n 111 supra, at 213-214.
} 
effects); they must consider the nature and location as well as the scale of projects; and they must examine the cumulative effect of projects, rather than splitting them into smaller units and considering them individually. ${ }^{118}$

These recursive review processes have given rise both to substantial amendments to the EIA Directive and to the enactment of new legislation. In the original Directive, consideration of alternatives was an adjunct to information provided by developers, but the failure to take them into account was recognised by the European Commission as a major deficiency in the quality of environmental impact statements during the first phase of implementation. Hence the amending Directive incorporates a mandatory requirement to provide information on 'the main alternatives studied by the developer' and 'the main reasons for his choice, taking into account the environmental effects.' In relation to transparency and participation, similarly, amendments to the EIA Directive in 1997 and again in 2003 broadened the categories of information to be made public; required affected groups to be notified of participation opportunities, which must be 'early and effective', when all options are under consideration and before the decision is taken; strengthened opportunities for public participation in the assessment of transboundary projects; and introduced mandatory reason-giving requirements, including a response to 'the concerns and opinions expressed by the public'. ${ }^{119}$ Beyond these amendments to the original legislation, the EU enacted a new Strategic EIA Directive in 2001, based on lessons emerging from reviews of the EIA Directive. This Directive applies to broad plans and programs rather than just individual projects, places stronger emphasis on advance consideration of alternatives, and invites the European Commission to consider the possibility of subsequently extending the scope of strategic EIA to other areas and sectors.

Inspired by these developments, the European Commission has begun to experiment with the elaboration of EIA into a form of advance sustainability appraisal of EU legislative and policy proposals, taking account of economic and social as well as environmental factors. This would involve the amalgamation of existing sectoral impact assessment processes into a single, standardised procedure, and is viewed as an internal testing ground for the possible future application of a similar system in the Member States. ${ }^{120}$

\section{Democratising Destabilisation}

In this section the focus shifts from law to democracy. Even if rule-making systems of the type we have been describing are accountable and produce formal rules to which sanctions can be attached, they are not therefore democratic. Democracy requires not only that citizens be equally subject to the law, but also that they be jointly and equally its authors. In this regard, peer review and DDP more generally are doubly suspicious: first because the rules they make are not validated by the familiar processes of representative democracy through legislative enactment and control; second, and worse still, in deviating from the norms of representative democracy and principal-agent accountability, they appear to deliver decision making into the hands of a technocratic elite,

\footnotetext{
118 ibid, at 215 and 217.

119 Quoted in ibid, at 222 and 219. The 2003 amendments to the EIA Directive were largely based on the incorporation of requirements arising from the EU's adhesion to the UN's Aarhus Convention on access to information, participation in decision making, and access to justice in environmental matters.

120 ibid, at $223-224$.
} 
whose potentially self-interested manipulations are cloaked in the robes of dispassionate deliberation. A comprehensive democratic justification of this new governance architecture would be an independent project in political theory and well beyond the scope of this article. For now, we want to show that the second, technocratic concern is not only unfounded because of the way peer review deliberations expose technical expertise to searching public scrutiny, but also that this scrutiny may have broader and potentially democratising effects on the new system of governance taken as a whole. Put another way, our claim is not the new architecture of peer review is itself intrinsically democratic, but rather that it destabilises entrenched forms of authority - starting with, but not limited to, technocratic authority - in ways that may clear the way for an eventual reconstruction of democracy. Here are some of the ways by which this destabilisation occurs.

\section{A Transparency and Participation as Procedural Requirements}

A necessary foundation for all forms of democratising destabilisation is transparency: the citizen's right to know not just what the authorities are deciding but also the evidence and arguments motivating their decisions. Without such a free flow of information, it is impossible to contest official proposals by drawing on the expanded range of feasible alternatives generated through the EU's experimentalist governance architecture. In other words, although transparency is not itself destabilising, it is the precondition for everything that is.

The EU was not initially transparent, but it is becoming so. The Treaties do not explicitly guarantee the principle of transparency, but commitments to openness, accessibility of information, and publicity of decision making in EU networked governance have progressively deepened over the past decade. Such transparency requirements both build on an earlier set of procedural safeguards in European administrative proceedings established by ECJ decisions and have served in turn as the basis for further commitments to ensure the active participation of a broad range of stakeholders in EU governance.

There is no general administrative procedural law in the EU. But the case-law of the European Courts has created a coherent set of horizontal principles and procedural safeguards applicable across distinct policy areas. These principles and safeguards regulate administrative behaviour not only by European institutions themselves, but also by national authorities participating in the 'mixed' or 'composite' multi-level proceedings characteristic of EU networked governance. As Sabino Cassese, the dean of European administrative law scholars observes, these safeguards include: the right to 'good administration' (now explicitly incorporated into the Charter of Fundamental Rights); 'the duty to impartially, accurately and comprehensively represent the facts'; 'remedies against bureaucratic inertia'; 'the duty to notify interested parties that an administrative proceeding has begun'; 'the duty to exercise diligence'; and 'the duty to conclude the proceeding within a reasonable time'. Most fundamental of all is 'interested parties' right to information and to be heard at various stages in the decisionmaking process', which Francesca Bignami terms a 'first-generation participation right'. ${ }^{121}$ These administrative rights and duties are not innovative except insofar as

${ }^{121}$ S. Cassese, 'European Administrative Proceedings', (2004) 68 Law and Contemporary Problems 21, at 25; F. Bignami, 'Three Generations of Participation Rights before the European Commission', (2004) 68 Law and Contemporary Problems 61, at 63-67. 
they extend to the EU best-practice protections against arbitrary and unfair treatment available to citizens in the Member States. But such procedural safeguards nonetheless constitute an indispensable foundation for more ambitious claims to transparency in administrative decision making.

In the EU, pressure for transparency originated from the Nordic countries, particularly Sweden, where access to official information antedated representative democracy as a form of popular accountability. When Sweden and Finland joined the EU in 1995, they pushed for procedural reforms favouring transparency in the Council and European Commission, adding their weight to that of Denmark and the Netherlands which had long urged such measures. These Member States then won broader protection for the principle of transparency through successful litigation before the European Courts. Treaty reform followed in Amsterdam in 1997. Since then the Courts have extended procedural safeguards further to ensure the deliberative quality of comitological decisions, for example by scrutinising the methods by which expert opinion is solicited and evaluated. Although the ECJ has not accorded transparency 'the legal status of a general principle of Community law' or recognised a 'general right of freedom of information', it has interpreted grounds for exceptions to them narrowly. The 'right of access to documents' is guaranteed by the Charter of Fundamental Rights, and improved regulations for public access to EU documents were adopted in 2001, which apply to not only to the European institutions themselves, but also to any agencies established by them. ${ }^{122}$

Although transparency as a legal right in the EU refers mainly to individual access to documents, this principle increasingly shapes the provision of information by European and Member State administrative bodies engaged in networked governance. For transparency to serve as an effective tool for public accountability, and potentially for democratising destabilisation, information about administrative decision making must not only be open, in the narrow sense of not closed, but freely and widely accessible. Knowledgeable observers of the EU see developments moving in just this direction. Thus as Bignami remarks:

\footnotetext{
The new commitment to transparency has affected the Commission most precisely in the administrative arena. Traditionally, only important, new policy initiatives of the Commission were publicised in advance through White and Green Papers. Now, certain committees of national representatives and certain divisions within the Commission have begun making transparent the more mundane activity of interpreting, implementing, and updating existing legislative frameworks... . The Commission, on its own initiative or while functioning as the secretariat for committees of national regulators, has recently begun placing the committees' work agendas and draft proposals on its website, marking a dramatic shift from the past. ${ }^{123}$
}

Geradin and Petit likewise identify a progressive elaboration of transparency requirements in the operation of EU networked governance. The first generation directives for the regulation of privatised infrastructure industries established only modest transparency requirements, such as the obligation for national authorities in telecommunications to make their decisions public and give reasons for them in resolving interconnection disputes. But in more recent framework directives establishing

\footnotetext{
122 P. Craig and G. de Búrca (eds), EU Law: Text, Cases, and Materials (Oxford University Press, 3rd edn, 2003), at 392-396; Bignami, ibid, at 68-71. On judicial review of comitology proceedings, see E. Vos, 'EU Committees: The Evolution of Unforeseen International Actors in European Product Regulation', in C. Joerges and E. Vos (eds), EU Committees: Social Regulation, Law and Politics (Hart, 1999), at 27-30. 123 Bignami, op cit $\mathrm{n} 121$ supra, at 71.
} 
networked agencies, they discern a 'noticeable evolution' towards more robust insistence on transparency at both EU and national levels, as in the case of the recent railway safety directive, which requires national authorities to carry out their tasks 'in an open, non-discriminatory and transparent way', as well as to 'allow all parties to be heard and give reasons for decisions'. ${ }^{124}$ In a similar vein, as we have seen in earlier sections, EMEA now publishes the names of participating scientific experts and nominating authorities on its website, while EFSA, whose core mission explicitly includes transparency, goes further still in posting minutes of all its Board Meetings online and opening some of them to the public.

As with transparency, there is an increasing tendency in EU networked governance to establish procedural requirements for ensuring active participation by a broad range of stakeholders in regulatory decision making, including civil society associations and NGOs as well as industry bodies, social partners, and other interested parties. ${ }^{125}$ Both the European Railway Agency and national rail safety authorities are obliged to 'consult social partners and organisations representing rail freight customers and passengers at European level. ${ }^{126}$ Committees of European financial regulators are expected to 'consult extensively and at an early stage with market participants, consumers and end-users in an open and transparent manner'. ${ }^{127}$ Other examples discussed in earlier sections include: the involvement of consumer groups as well as industry in the Florence Electricity Forum; the representation of patient organisations (but not the pharmaceutical industry) on the board of EMEA, following the 2004 legislative review of its operations; and the incorporation of 'professionals from the sectors concerned' as non-voting members on the board of EMSA.

The WFD and its CIS provide a striking illustration of the broader trend to extend procedural requirements in EU networked governance from transparency to participation. The CIS is formally committed to 'the principles of openness and transparency encouraging creative participation of interested parties'. NGOs and other stakeholders are invited to nominate experts to the working groups, to comment on guidance documents, and to attend meetings of the SCG and the working groups themselves 'when they can contribute to the work with a specific expertise'. In addition, the WFD requires Member States to 'encourage the active involvement of all interested parties' in its implementation, particularly in the "production, review, and updating of ... river basin management plans'. ${ }^{28}$

\section{$B \quad$ Widening the Circle of Actors and Alternatives}

\section{Opening the $O M C$}

The diffusion of procedural commitments to transparency and participation in EU networked governance has had a democratising destabilisation effect in terms of stimulating demands to widen the circle of actors and alternatives involved in policy making

124 Geradin and Pettit, op cit n 5 supra, at 28-29.

125 ibid, at 29-31; Bignami, op cit n 121 supra, at 72-82.

126 Geradin and Petit, op cit $\mathrm{n} 5$ supra, at 29-30.

127 Decision 2001/527/EC, cited in Bignami, op cit $\mathrm{n} 121$ supra, at 71.

${ }^{128}$ CIS Strategy Document quoted in Scott and Holder, op cit n 111 supra, at 228; Water Framework Directive quoted in A. Barreira and G. Kallis, 'The EU Water Framework Directive and Public Participation in Transboundary River Basin Management', in J.G. Timmerman and S. Langass (eds), Environmental Information in European Transboundary Water Management (IWA Publishing, 2003), at 102. 
at the national as well as the European level. The best documented examples here concern the OMC processes in employment and social inclusion/protection. ${ }^{129}$

Especially in its early years, the EES was widely regarded as a narrow, opaque, technocratic process involving EU officials and domestic civil servants oriented towards relations with European institutions, rather than a broad, transparent process of public deliberation open to all those with a stake in the outcome. Official efforts to involve non-state actors in the EES were primarily directed at unions and employers' organisations, whose cooperation is necessary for progress on issues subject to collective bargaining such as flexibility and 'modernisation' of work organisation. The European social partner organisations (ETUC, UNICE/UAPME, and CEEP) are formally consulted about the employment guidelines, regularly comment on the evolution of the EES, and since 2003 participate in an annual tripartite social summit preceding the spring European Council. At the national level, most Member States have sought to involve unions and employers' associations in the preparation of their National Action Plans, often resulting in the production of some kind of jointly agreed text incorporated into or appended to the NAP. The EES has not simply followed existing national patterns of social partnership (or lack thereof), but has also stimulated the creation of new consultative fora in some countries (eg France, Greece) or their reinvigoration after a period of decline in others (eg Sweden). ${ }^{130}$

But the creation of a European-wide employment strategy, based on comparison of national policies and performance in reaching common objectives and targets, has stimulated vocal demands to participate in the process by other non-state and subnational actors, notably social NGOs and local/regional authorities. The European Anti-Poverty Network (EAPN) in particular has fought hard for a voice in the EES. The network produces regular independent reports on employment policy and organises self-funded conferences on how to make the employment strategy work for social inclusion. On this basis, EAPN, together with other social NGOs such as organisations representing the disabled, has pressed for the right to be consulted alongside the social partners about the employment strategy at both EU and national levels. In some Member States, like Spain, Portugal, and Ireland, the NAP/empl process has been opened up to NGO consultation without much controversy. But in countries with highly institutionalised social partnership arrangements such as Belgium and Denmark, there has been strong resistance to any involvement by civil society groups. Perhaps the most interesting case is that of Sweden, where a network of social NGOs consciously set out to 'break the monopoly' of the social partners over the NAP/empl, and was invited to a separate dialogue on employment policy by the Ministry of Industry, Employment, and Communications for the first time in 2003). ${ }^{131}$

From an early stage in the EES, local and regional authorities likewise began to demand the right to participate more fully in the process, lobbying at a European level through horizontal networks like the EU's Committee of the Regions, the Council of European Municipalities and Regions, and EUROCITIES. Between 1998

129 For a fuller discussion, see J. Zeitlin, 'The Open Method of Co-ordination in Action. Theoretical Promise, Empirical Realities, Reform Strategy', in Zeitlin and Pochet, op cit n 54 supra.

${ }^{130}$ For an authoritative overview, see F. Alacevich, Provomuovere il dialogo sociale. Le conseguenze dell'Europa sulla regolazione del lavoro (Firenze University Press, 2004).

${ }^{131}$ K. Jacobsson, 'Trying to Reform the "Best Pupils in the Class"? The Open Method of Co-ordination in Sweden and Denmark', in Zeitlin and Pochet, op cit $\mathrm{n} 54$ supra. 
and 2001, the employment guidelines were progressively revised to call for the mobilisation of 'all actors at regional and local levels' in the implementation of the EES; local and regional authorities in particular were encouraged to develop their own territorial employment strategies and to 'promote partnerships between all actors concerned' in carrying them out. The European Commission organised a year-long campaign and consultation process on 'Acting Locally for Employment', and the European Parliament created a new budget line to support pilot projects that would 'encourage cooperation, improve knowledge, develop exchanges of information, promote best practices, support innovative approaches and evaluate experience gained in implementing the National Action Plans for Employment at local and regional level'. ${ }^{132}$ Among the innovative projects supported under this budget line are numerous Local and Regional Action Plans for Employment (LAPs and RAPs); the development of local and regional employment indicators; and the creation of a European network for identification, dissemination, and exchange of good practices in local and regional employment development (IDELE), capped by an annual Local Development Forum. ${ }^{133}$

These EU initiatives have met with an active response from local and regional authorities in many Member States. In Sweden, associations of local authorities, county councils, and municipalities have sponsored a proliferation of LAPs, 'intended to be tangible action plans, i.e. operational documents which should be followed up and results evaluated', and have successfully pressed the central government for 'more of a bottom up perspective' in the NAP/empl. ${ }^{134}$ According to a representative of the Swedish Association of Municipalities and County Councils, the EES thus appeared as 'the answer to a silent prayer' by his members who had been searching for ways to expand their participation in the country's historically centralised labour market and employment policies. ${ }^{135}$ In Denmark, where the associations of local and county authorities already participate in the social partner consultation about the NAP/empl, they have also supported a number of municipalities in developing LAPs, and the Ministry of Employment is expected to integrate their work more fully into future policy-making. ${ }^{136}$ Often, too, local authorities have used EU support to integrate the EES into their own employment policymaking. Perhaps the most imaginative such initiative was undertaken by the east German town of Döbeln, which used European

${ }^{132}$ European Commission, Acting Locally for Employment: A Local Dimension for the European Employment Strategy, COM (2000) 629 final, Brussels, 7 April; European Commission, Strengthening the Local Dimension of the European Employment Strategy, COM (2001) 629 final, 6 November; Committee of the Regions, The Local Dimension of the European Employment Strategy: The Impact of the Committee of the Regions (Committee of the Regions, 2001), esp at 20-24; Council of European Municipalities and Regions, Governance and the Open Method of Coordination (CEMR, 2001); EUROCITIES, Strengthening the Local Dimension of the Future European Employment Strategy: Eurocities Recommendations (EUROCITIES, 2001).

${ }_{133}$ Engender ASBL, Review of the Implementation of the Guidelines on Local Development in the Employment NAPS from 1998 to 2001 Across the EU, Synthesis Report, April 2002; Groupe Bernard Brunhes Consultants, Strengthening the Local Dimension of the European Employment Strategy: Feasibility Study on Indicators for Local and Regional Levels and for the Social Economy, Paris, December 2003; European Commission DG EMPL, Activity Report to EMCO Local Employment Development: 2001-2004, EMCO/ 14/220404/EN, 2004.

134 Jacobsson, op cit $\mathrm{n} 131$ supra, at 114-115.

135 Statement made at a public conference on The European Employment Strategy: Discussion and Institutionalisation, International Trade Union House, Brussels, 30-31 August 2004.

136 Jacobsson, op cit n 131 supra, at 115-116. 
funding to benchmark its local labour market situation against those of other areas experiencing similar structural problems of industrial decline. ${ }^{137}$

In the Social Inclusion OMC, by contrast, 'mobilizing all the relevant bodies' was defined from the outset as one of its four core objectives. Hence participation by non-state and subnational actors has been more active and less contested than in the EES. Thus EAPN, which is financially supported by the EU under successive Community Action Programmes, has been granted a semi-official place in the Social Inclusion process. The network is consulted on key elements of the process such as the indicators, NAP common outlines, and objectives, while also regularly co-organising conferences and roundtables financed by the European Commission. At the same time, however, EAPN also independently reviews and critically evaluates the NAPs and Joint Inclusion Reports, pushing for greater Member State commitment, a stronger social rights approach, and a more general 'right to be heard' on the part of people experiencing poverty and organisations representing them. Other transnational NGO networks active in the Social Inclusion process include FEANTSA (the European Federation of National Organisations Working with the Homeless) and ATD Fourth World (an international organisation of people experiencing extreme poverty), both of which have also published evaluations of the NAPs/incl and JIRs based on submissions from their national affiliates, as well as the Platform of European Social NGOs to which all of these groups belong. ${ }^{138}$

At the national level, the Social Inclusion process has stimulated the development of new consultative bodies and structures to facilitate input from NGOs. In Finland, for example, both the 2001 and the 2003 NAPs/incl were drafted by a joint committee of civil servants and NGOs. In the UK, EU criticisms of the over-centralised character of the first NAP/incl resulted in the establishment of a new dialogue between the Department of Work and Pensions and a Social Policy Task Force of NGOs, which 'gave anti-poverty groups and networks access to central government civil servants in a way that simply had not been possible before within the domestic arena', thereby not only providing opportunities for NGOs to mobilise but also for civil servants to 'break out of the traditional bureaucratic routines' and 'do something different'. One striking consequence has been the creation of a joint Participation Working Group aimed at 'enabl[ing] people in poverty to participate in the development of the UK NAP 2005 and beyond by establishing a real partnership [with] government at all levels in order to improve anti-poverty policy and practice... ${ }^{139}$ In other Member States, such as Sweden, Germany, Denmark, and the Netherlands, new or existing national networks of social NGOs have been mobilised to coordinate their participation in the Social Inclusion process. NGO bodies have likewise been given a formal role in monitoring

137 M. Nauerz, Does the European Employment Strategy Lead to a Soft Form of Europeanisation? An Analysis of the 'Local Dimension' in Germany, unpublished Masters Thesis, College of Europe, Bruges, 2004.

138 For reports, position papers, information bulletins, and conferences on the European Social Inclusion process produced by these organisations, see the relevant sections of their websites: EAPN: http://www.eapn.org/code/en/publ.asp?section=x1x; FEANTSA: http://www.feantsa.org/code/ en/theme.asp?ID=6; Social Platform: http://www.socialplatform.org/Policy.asp?DocID=11508 (accessed 19 March 2007). For other assessments of their role in the Social Inclusion process, see C. de la Porte and P. Pochet, in Zeitlin and Pochet, op cit n 54 supra; K. Armstrong, 'Tackling Social Exclusion through the OMC: Reshaping the Boundaries of European Governance', in Börzel and Cichowski, op cit $\mathrm{n} 108$ supra.

139 K. Armstrong, 'How Open is the United Kingdom to the OMC Process on Social Inclusion?', in Zeitlin and Pochet, op cit n 54 supra, at 297, 306. 
the implementation of the NAPs/incl in a number of countries like Denmark, Portugal, and Luxembourg. ${ }^{140}$

Establishing European procedural requirements for the participation of non-state and subnational actors in the national implementation of OMC processes has proved controversial. In the 2003 revision of the employment guidelines, for example, Member State representatives insisted in the name of subsidiarity on watering down European Commission proposals for promoting 'the mobilisation of all relevant actors', including both civil society and regional and local authorities. ${ }^{141}$ But the Kok Employment Task Force emphasised 'mobilizing for reforms' through 'better governance' as one of its key messages, calling for consultation of social partners and civil society in the preparation of the NAPs/empl and the creation of 'reform partnerships' involving local authorities alongside social partners and public agencies, ${ }^{142}$ and a similar injunction figured as one of four common recommendations to all Member States in the 2004 Joint Employment Package. ${ }^{143}$ In preparing their 2005 National Reform Programmes as part of the relaunched Lisbon Strategy for Growth and Jobs, Member States were enjoined by the European Council and the European Commission to 'promote dialogue and partnership between all relevant bodies', including civil society and local and regional authorities as well as social partners and national parliaments. ${ }^{144}$ The new overarching objectives for the 'streamlined' OMC on social protection/inclusion incorporate a commitment to 'strengthen governance, transparency, and the involvement of stakeholders in the design, implementation and monitoring of policy'. They thus explicitly extend the practice of open and extensive stakeholder involvement developed in social inclusion not only as a default norm for the OMC in pensions and health care but also 'as an objective for social policy making more generally'. ${ }^{145}$

\section{The EU and the Other: Accession as Mutual Transformation}

Another and unlikely case of democratising destabilisation concerns the accession of new Central and East European states to membership in the EU. The case is, at first glance, unlikely to contribute to the democratising destabilisation of either the EU or the accession states because of the enormous, manifest disparities in power and wealth between the established members and the accession candidates. Given the raw and plausible promise of prosperity that membership in the EU confers, and the unilateral formal authority of the EU to set the terms of accession, it seems that any changes wrought by enlargement would be limited to accommodations to EU practices in accession candidates seeking to comply with admission requirements. The obvious and sufficient explanation for their willingness to change is simply the rewards for successfully doing so. Indeed, one strand of literature regarding the accession process treats it as an exemplary case of the transformative effects of 'high-powered' conditionality, in

${ }^{140}$ Zeitlin and Pochet, op cit n 54 supra; European Commission and Council of the European Union, Joint Report by the Commission and the Council on Social Inclusion, Document 7101/04, Brussels, 5 March 2004; European Anti-Poverty Network, National Action Plans on Inclusion 2003-2005: Where Is the Political Energy? EAPN's Response to the Second Round of Plans (EAPN, 2003), at 13-17.

${ }_{141}$ Zeitlin (2005), in Zeitlin and Pochet, op cit n 54 supra, at 485.

142 Employment Taskforce 2003, Jobs, Jobs, Jobs: Creating More Employment in Europe: Report of the Employment Taskforce Chaired by Wim Kok, European Commission, Brussels, November 2004, at 56-58.

$143 \mathrm{ibid}$; Council Recommendation of 14 October 2004 on the Implementation of Member States' Employment Policies (2004/741/EC), [2004] OJ L 326/47.

${ }^{144}$ European Commission, Working Together for Growth and Jobs, op cit n 61 supra, at 6.

${ }^{145}$ European Commission, Working Together, Working Better, op cit n 61 supra. 
which the extraordinarily attractive prospect of EU membership motivates widespread governance reforms that apparently cannot be achieved through the lower-powered inducements of conditions attached to World Bank or IMF loans. ${ }^{146}$ But this interpretation overlooks, first, the way the accession process. because of its very complexity operates by means of framework rule making and revision familiar from internal domains of EU regulation. Second and consequently, this interpretation overlooks the democratising destabilisation effects on the EU itself produced by the recursive rule making carried out in collaboration between the EU and accession candidates.

Eastern enlargement presented the EU with an unprecedented set of challenges. The number of candidate countries far exceeded those of previous enlargements, and the resulting concerns about the EU's absorptive capacities were exacerbated by serious doubts about the commitment and capability of ex-Communist states to implement the acquis communautaire. ${ }^{147}$ Thus from an early stage, the Council and the European Commission realised that eastern enlargement would overwhelm the classic Community Method of individualised accession negotiations followed by centralised, ex post monitoring and enforcement of compliance with EU rules. The 'Copenhagen criteria' adopted in 1993 therefore required prospective Member States to have established stable, democratic institutions (guaranteeing human rights, the rule of law, and protection of minorities); a functioning market economy capable of withstanding competitive pressures within the EU; and the ability to adopt the acquis. Over the next few years, the EU became increasingly concerned that candidate countries demonstrate the 'administrative capacity to apply the acquis', which was progressively defined as an essential condition for accession alongside the original Copenhagen criteria. Yet the European Commission encountered considerable difficulty in operationalising this latter criterion, since 'there are no EU treaty provisions regarding the design of the Member States' public administrations and no general body of European law in the public administration field', while national administrative structures and regulations vary widely across the EU. ${ }^{148}$

The real breakthrough in the accession process came with the European Council's adoption in December 1997 of the 'Agenda 2000', a new enlargement strategy proposed by the European Commission, which closely resembled the new architecture of

146 For a particularly clear and strong statement of this interpretation, see M. Vachudova, Europe Undivided: Democracy, Leverage, and Integration After Communism (Oxford University Press, 2005). Much of the recent literature on EU enlargement has focused on the balance between external incentives, social learning, and lesson drawing in shaping the behaviour of candidate countries, placing primary though not exclusive weight on the causal impact of political conditionality. For authoritative overviews, see F. Schimmelfennig and U. Sedelmeier (eds), The Europeanization of Central and Eastern Europe, Cornell University Press, 2005); W. Jacoby, The Enlargement of the European Union and NATO: Ordering from the Menu in Central Europe (Cambridge University Press, 2004).

147 In the case of Finland and Sweden, which joined the EU in 1995, not only did EU negotiators fail to raise the question of administrative capacity, but they also accepted vague commitments from these countries to establish the necessary procedures for implementing the acquis after accession: see P. Nicolaides, 'Preparing for Accession to the European Union: How to Establish Capacity for Effective and Credible Application of EU Rules', in M. Cremona (ed), The Enlargement of the European Union (Oxford University Press, 2003), at 47.

148 A. Dimitrova, 'Enlargement, Institution-Building and the EU's Administrative Capacity Requirement', (2002) 25 West European Politics 171, at 177-182, quotation at 180; E. Tulmets, 'The Introduction of the Open Method of Coordination in the European Enlargement Policy: Analysing the Impact of the New PHARE/Twinning Instrument', (2005) 3 European Political Economy Review, 54, at 55-56; U. Sedelmeier, 'Eastern Enlargement', in Wallace et al, op cit n 7 supra. 
networked, experimentalist governance then emerging, as we have seen, across other areas of EU policy making. ${ }^{149}$ This new strategy established an iterative procedure for promoting, monitoring, and evaluating the candidate countries' advance towards the common European objectives embodied in the augmented Copenhagen criteria. These common objectives were adapted to divergent local contexts through bilateral Accession Partnership agreements and National Plans for the Adoption of the Acquis drawn up and regularly updated by the candidate countries themselves. The National Plans in turn required elaboration of Institution-Building Plans for establishing the administrative capacities needed to implement the acquis. Together, these nested agreements and plans defined benchmarks that the candidate countries were expected to reach, and served as the basis for national programs of EU technical assistance, aimed at helping them to build the capacity to meet these goals through exchange of best practices with Member State administrations. The European Commission evaluated progress against the jointly agreed goals, using a detailed set of common indicators and monitoring data generated by the national planning process, through a series of Regular Reports on each of the candidate countries, whose recommendations played a key part in the final accession decision. ${ }^{150}$

Crucial to the effectiveness of the new enlargement strategy was the transformation of EU technical assistance through the practice of institutional 'twinning': the secondment to candidate country administrations of Member State practitioners experienced in the national implementation of EU rules in key policy areas. Whereas before 1997, EU technical assistance had focused primarily on facilitating economic liberalisation in response to ad hoc governmental requests, it was now reoriented towards building institutional capacity to implement the acquis in the candidate countries. Although the new procedures tied twinning projects more firmly to the EU's accession requirements, they also gave candidate countries considerable leeway in the selection of cooperation partners and administrative/institutional models to adapt to their own national context. Project teams were chosen by candidate country administrations on the basis of presentations by Member States, which included detailed information about national approaches to the legal transposition of directives and the informal solutions developed for their implementation. Often, too, twinning project teams involved practitioners from multiple Member States, encouraging comparative discussion of the merits of alternative approaches to the implementation of the acquis in particular fields. Not only did the twinning programme serve as a vehicle for selective transfer of expertise to new Member States in line with the latter's priorities and policy choices, but it also promoted reciprocal learning through mutual exchange in the old Member States themselves. Thus the competitive selection process for twinning projects pushed national administrations to evaluate critically their own internal capacities and learn how to present their expertise to partners from very different backgrounds. In some cases, moreover, practitioners from old Member States discovered that solutions developed in candidate countries could be also useful for tackling similar problems back home. So successful did the twinning process prove in paving the way for enlargement that this approach has since been embraced as a useful mechanism for enhancing administrative coordination between Member States within the EU, while also becoming the template for the EU's

\footnotetext{
149 Tulmets, ibid, at 57-63.

150 ibid, at 61; Vachudova, op cit n 146 supra, at ch 5; Sedelemeier (2005), ibid.
} 
external technical assistance programs as part of its new 'European Neighbourhood' and development aid policies. ${ }^{151}$

In certain technically complex policy fields, such as pharmaceutical authorisation and environmental protection, the EU also sought to 'smooth' implementation of the acquis in the accession countries by integrating them into horizontal regulatory networks of European and national authorities. Thus in pharmaceuticals the European Commission created a Pan-European Regulatory Forum (PERF) involving experts from both old and new Member States coordinated by EMEA, while in environmental protection an Accession Countries Network for the Implementation and Enforcement of Environmental Law (AC IMPEL) was established alongside the existing IMPEL network in the old Member States and merged with the latter in 2003. In both sectors these networks served not only as mediators between the European Commission and regulatory authorities in the candidate countries, but also as fora for cooperation, dialogue, and mutual learning, as well as for the identification of specific administrative capacity building needs to be addressed through twinning projects. As in the case of twinning, moreover, participation in these horizontal regulatory networks enabled candidate countries to learn not only about those parts of EU sectoral legislation 'which are uniformly implemented in all Member States, but also those parts which allow for some flexibility and which are implemented in different ways in the Member States'. ${ }^{152}$

Alongside the formal acquis, the enlargement process pushed the accession countries to adopt the new procedural requirements of transparency emerging within the EU's new governance architecture. Thus to a much greater extent than other recently established democracies in Latin America and most of the former Soviet Union, the new Central and East European Member States have moved rapidly to introduce transparency-supporting institutions such as freedom of information legislation, external audit and control mechanisms, and the appointment of ombudsmen to assist individuals in obtaining information about government abuses. In addition to specific information and publicity requirements built into recent directives, especially in the environmental field, the EU has indirectly helped to promote transparency within the new Member States through the external reporting and statistical capacity-building obligations associated with the accession process. And as in the old Member States

151 Tulmets, op cit n 148 supra; E. Tulmets, 'The Management of New Forms of Governance by Former Accession Countries of the European Union: Institutional Twinning in Estonia and Hungary', (2005) 11 European Law Journal 657; D. Bailey and L. De Propris, 'A Bridge Too Phare? EU Pre-Accession Aid and Capacity-Building in the Candidate Countries', (2004) 42 Journal of Common Market Studies 77; J. Kelley 'New Wine in Old Wineskins: Promoting Political Reforms through the New European Neighbourhood Policy', (2006) 44 Journal of Common Market Studies 29; T. Börzel and T. Risse, Venus Approaching Mars? The EU as an Emerging Civilian World Power, unpublished paper presented to the biennial conference of the European Union Studies Association, Montreal, 17-19 May 2007.

152 C. Koutalakis, 'Smoothing' Eastern Enlargement through New Modes of Governance? Conceptualising the Role of Independent Agencies and Non-Hierarchical Steering in Pre-accession Negotiations, NEWGOV Deliverables 14-D1, Free University, Berlin, 23 December 2004, at 33. According to Koutalakis (ibid, at 22-24), the implementation of the acquis by the accession countries was more complete in pharmaceuticals than in environmental protection, at least in part because of the closer contact between experts from the old and new Member States in PERF than in AC IMPEL before the latter's merger with IMPEL. On PERF, see also H. Prange, New Mechanisms of Europeanisation in the Process of EU Enlargement: The Example of Pharmaceutical Regulation, Queen's Papers on Europeanisation no 8, Queen's University, Belfast, 2002; on IMPEL, see M. Martens, 'National Regulators between Union and Governments: A Study of the EU's Environmental Policy Network IMPEL', in Egeberg, op cit $\mathrm{n} 5$ supra. 
themselves, these EU transparency requirements have created democratising destabilisation effects in the accession countries, as domestic actors use information provided to European bodies to challenge governmental policies and push for further opening up of public decision making. ${ }^{153}$

As we have already seen in the case of the twinning programme, the enlargement process has exerted a transformative impact not only on the accession countries, but also on the EU and the old Member States, through the re-importation of governance innovations from the periphery to the centre. Other noteworthy instances of this dynamic include: the extension to all EU Member States of internal market scoreboards developed for benchmarking the transposition and implementation of directives by candidate countries, ${ }^{154}$ the proposed creation of a network of independent authorities to assist the European Commission in the enforcement of Community state aid rules, explicitly modelled on the experience of national monitoring authorities created during the accession process (discussed in section III C 2 above); and the institutionalisation of collective evaluation mechanisms such as standing committees of national representatives, mutual monitoring procedures, and joint inspection teams for border control and policing originally established to ensure the full implementation of the Schengen acquis in the new Member States. ${ }^{155}$ But the most striking example of the democratising destabilisation effect of enlargement on the EU is undoubtedly the power to sanction Member States for persistently breaching the common values of the EU pre-emptively incorporated into Article 7 of the Amsterdam Treaty, which as we have seen (in section III D 2 above), led first to the creation of a network of independent experts issuing regular monitoring reports on the situation of fundamental rights in EU Member States, and then to the foundation of an EU Fundamental Rights Agency.

\section{Against Exceptionalism: The EU as Forerunner, Not Outlier}

The discussion so far treats the innovative governance architecture of the EU as embodying general principles-for instance, dynamic accountability as realised through peer review-developed to respond effectively to conditions of persistent diversity, complexity, and volatility. But there is only one EU. It is sui generis in the sense that it is the only large polity, perhaps the only polity of any size to rely so thoroughly in rule making and even now the articulation of rights on this new experimentalist architecture. If the new architecture is indeed an effective response to a general condition, however, then only a wildly improbable distribution of enabling conditions (the preconditions for experimentalist governance) could explain the emergence in the EU and only there of collective problem-solving institutions with potentially great general utility. Alternatively, it may be that the EU is not nearly as distinct as it so far appears, and that experimentalist institutions are diffusing less conspicuously both above and below the level of whole polities. By way of conclusion, we argue

\footnotetext{
${ }^{153}$ A. Grigorescu, 'Transferring Transparency: The Impact of European Institutions on East-Central Europe', in R. H. Linden (ed), Norms and Nannies: The Impact of International Organizations on the Central and East European States (Rowman \& Littlefield, 2002); Vachudova, op cit n 146 supra, at 186-188.

${ }^{154}$ Sedelmeier (2005), op cit $\mathrm{n} 148$ supra, at 406.

155 J. Monar, 'Maintaining the Justice and Home Affairs Acquis in an Enlarged Europe', in J. Apap (ed), Justice and Home Affairs in the EU: Liberty and Security Issues after Enlargement (Edward Elgar, 2004); Monar (2005), op cit $\mathrm{n} 14$ supra.
} 
in favour of this latter alternative, looking briefly at the emergence of experimentalist governance in some key areas in the US and in the global trade regime to underscore that the EU is a forerunner not an outlier.

\section{A America Leapfrogged? Has the Baton of Regulatory Innovation Been Passed?}

Consider first the view that Europe is indeed singular, or if a pioneer so isolated as to seem more nearly an exception than an avant garde. Evidence for this view might be drawn from a comparison with the development of environmental regulation in the USA. Starting in the late 1960s, the USA pioneered technology-forcing regulation: statutes such as the Clean Air and Clean Water Acts that set precisely defined but previously unimaginable goals for technological improvement in the (partially met) expectation that the prospect of sanctions would create the incentive for the innovations that compliance supposed. As the limits of ex ante definition of feasibly 'impossible' goals became more and more evident, there was a shift during the 1990s in many programmes in the direction of what we are here calling experimentalist governance. ${ }^{156}$ These programmes encountered political opposition in the later years of the Clinton administration. Whether or not this opposition was an expression of some ineradicable structural incapacity of US environmentalism to accommodate the new methods, or was rather just an expression of the kinds of resistance and hesitation that accompanies any shift in regime is currently impossible to say. The Bush administration savaged the experimentalist programmes along with many traditional areas of environmentalism, so that for now it is reasonable to say that the EU has indeed leapfrogged the USA in this domain. ${ }^{157}$

But in several key domains outside environmentalism, there were noteworthy successes in the USA of experimentalist rule making by framework elaboration and revision. The most widely discussed example is education, where the bipartisan No Child Left Behind Act of 2000 formalised and generalised to the whole country a series of experimentalist reforms of public education originating in states such as Texas and Kentucky. To respond to the needs of heterogeneous classes, with many students arriving without the whole panoply of middle-class family support, required a thorough re-organisation of the school: a re-organisation aimed at teaching pupils complex skills regardless of their starting point, rather than communicating information to them on the assumption that they started with the knowledge of how to use what was communicated. After more than two decades of desperate experimentation, reformers settled in the mid-1990s on an approach that, as in the case of EU experimentalist governance, allows effective reorganisation to proceed by using partial solutions, and without presupposing any definitive model of the ultimate goal. The core idea is to obligate states to define, with reference to each other and national standards, 'adequate' educational performance - the equivalent of 'good' water status - and then

156 Examples include the Toxics Release Inventory, the Massachusetts Toxics Use Reduction Act, Habitat Conservation Plans, the Chesapeake Bay Program, and Project XL. For a fuller analysis, see B. Karkkainen, A. Fung and C.F. Sabel, 'After Backyard Environmentalism: Toward a PerformanceBased Regime of Environmental Regulation', (2000) 44 American Behavioral Scientist 692.

157 D. Vogel, 'The Hare and the Tortoise Revisited: The New Politics of Risk Regulation in Europe and the United States', in Levin and Shapiro, op cit n 86 supra; H. Selin and S.D. VanDeveer, 'Raising Global Standards: Hazardous Substances and E-Waste Management in the European Union', (2006) 48(10) Environment 6; T. Buck, 'Standard Bearer: How the EU Exports Its Laws', Financial Times, 10 July 2007. 
to hold individual schools and school districts accountable for achieving these (corrigible) goals by means of their own choosing. In practice, standard tests are used not only to reveal shortcomings in pupils' learning strategies, but also the staff's teaching strategies, and the defects in the organisation of schools and school districts that underlie these failures. The aim of institutional reform, then, is to rebuild classes, schools and school systems so that these individual 'defects' can be identified and remedied systematically. The job of the teacher in this new public school is to organise the classroom to identify and remediate each pupil's difficulties; the job of the principal or school master to organise the school so that teams of teachers within and across grade levels help each other achieve this goal; and the job of the district or system head to organise the system so that principals have the authority and autonomy to do this. In the light of the accumulated experience of reform the goal and the tests measuring progress towards it are reformed as well. Think of all these as a series of nested 'common implementation strategies,' with a vengeance.

Reform by these means naturally reinforces and extends the new forms of school accountability from which they proceed. Teachers and school officials are accountable to each other through the performance measures that make diagnosis of problems possible in the first place. They are also accountable to the public. Thus in many states in the USA parents can compare the extent to which demographically comparable schools close the achievement gap between rich whites and other groups. This allows them to put pressure on school authorities, on politicians. ${ }^{158}$

These developments in US education reform have close parallels in the reorganisation of other public providers of key human services, such as mental health, child welfare, and policing. Together these examples demonstrate that experimentalist governance is hardly confined to the EU. ${ }^{159}$

${ }^{158}$ For a fuller account of these schooling reforms see J. Liebman and C.F. Sabel, 'A Public Laboratory Dewey Barely Imagined: The Emerging Model of School Governance and Legal Reform', (2003) 28 New York University Review of Law and Social Change 183; J. Liebman and C.F. Sabel, 'The Federal No Child Left Behind Act and the Post-Desegregation Civil Rights Agenda', (2003) 81 North Carolina Law Review 1703 .

159 This is as good a place as any to challenge the view that the explosion of rights in the EU will converge on US experience in an entirely different way: by emulating litigious American adversarial legalism fuelled by increasing reliance on rights: see Kelemen (2005), op cit n 15 supra; Kelemen (2006), op cit n 79 supra. There are two reasons for believing that this view is mistaken. One is that, as Burke, op cit n 86 supra, argues, most EU Member States currently lack the institutional machinery required to implement US-style adversarial legalism, such as contingency fees, large punitive damage verdicts, and a corps of aggressive plaintiff lawyers, while many European legal systems actively discourage rights litigation in favour of alternative complaint investigation and mediation procedures such administrative tribunals, collective bargaining agreements, or ombudsmen. A second and perhaps deeper reason is that, as we saw earlier, many of the rights in the EU rest on a social determination of collective obligationeg to 'reasonable accommodation' of disabilities - rather than on highly formalised interpretations of legal doctrine. This is why dispute resolution involving the rights frequently relies on non-judicial institutions - for instance, the Danish Ankerstyrelsen complaint boards for determination of disability and other 'social' rights. Finally, new forms of US public law litigation, which in the 1970s and 1980s was associated with the rise of litigiousness highlighted in Kelemen's view, are today contributing to the articulation of experimentalist rights and regulation principally in domains such as school reform, fair housing, child protective and mental health services: for detailed examples, see Sabel and Simon, op cit $\mathrm{n}$ 10 supra; K.G. Noonan, C.F. Sabel and W.H. Simon, The Rule of Law in the Experimentalist Welfare State: Lessons from Child Welfare Reform, unpublished paper, Columbia Law School, June 2007. 


\section{$B$ The EU as an Exemplary Architecture for Global Governance}

On the global level, too, developments cast doubt on the singularity of the EU's innovative regulatory architecture. In particular, the world trade regime embodied in the WTO, SPS and TBT appears to be reconciling global market integration with conflicting conceptions of legitimate social ordering by applying principles familiar from EU governance, although it is of course less well developed. Architecturally, the similarity is this: both the EU and the WTO anticipate that the freedom of (regional or international) trade they seek to foment will frequently conflict with, and need to be modified to accommodate a wide range of normative concerns embodied in the domestic laws and regulations of Member States trading in the relevant markets. Both, furthermore, permit members states to make domestic rules that inhibit trade on condition that the inhibiting rules adequately reflect the relevant regional or international standards. Thus the WTO SPS Agreement-which applies to agricultural, health and safety regulation - and the WTO TBT Agreement-which has been interpreted to apply to a broad range of domestic regulation not covered by the SPS - require that the trade-inhibiting rules, animated for example by a concern to protect public health or ensure product safety, have a 'basis' in international standards. ${ }^{160}$ To show that a basis exists, in the relevant sense, states must either use those standards or show through an acceptable rule-making process that the domestic rules are a reasonable departure from those standards, motivated, for example, by an assessment of health risks. ${ }^{161}$ Put another way, membership in the WTO and the EU is not equivalent to an agreement to substitute the particular, national rules with the general laws of efficient commerce. Rather, in joining these regimes, Member States are agreeing to remake their rules, in domain after domain, in light of the efforts of all the others to reconcile their distinctive regulations with general standards in whose determination they participate and that are assumed to be attentive to the interests of others elsewhere.

Of course, there are important differences between the EU and WTO regulatory regimes. Some, perhaps many, of the standard-setting bodies in the latter lack the sophistication and do not command the legitimacy of their EU counterparts, and peer review is often less deeply entrenched and formally protected at the global level. ${ }^{162} \mathrm{But}$ the architectural similarities are nonetheless striking enough to caution again against

${ }^{160}$ For overviews of the SPS and TBT agreements, see the website available at http://www.wto.org/english/ thewto_e/whatis_e/tif_e/agrm4_e.htm (accessed 19 March 2007).

161 The TBT (along with SPS) 'represents as big a paradigm shift to international economic law as, say, the prohibition on the use of force and the introduction of the Security Council with binding resolution and police powers represented within the classical world of international law'. These agreements produce 'an internationally determined normativity': H. Horn and J.H.H. Weiler, 'The European CommunitiesTrade Description of Sardines: Textualism and Its Discontent', in H. Horn and P. C. Mavroidis (eds), The WTO Case Law of 2002 (Cambridge University Press, 2005), at 250; cf also J. Scott, 'International Trade and Environmental Governance', (2004) 15 European Journal of International Law 307.

${ }^{162}$ For a critical discussion of decision-making practices within the Codex Alimentarius Commission and its implications for the legitimacy of transnational governance under the SPS Agreement, see A. Herwig 'Transnational Governance Regimes for Foods Derived from Bio-Technology and their Legitimacy', in C. Joerges, I.-J. Sand and G. Teubner (eds), Transnational Governance and Constitutionalism (Hart, 2004); and for an assessment of the democratising potential of growing trends towards transparency and civil society participation within the WTO more generally, see J. Steffek and U. Ehling, Civil Society Participation at the WTO - a Cure for its Democratic Deficit?, unpublished paper presented to the 3rd European Consortium for Political Research General Conference, Budapest, 8-10 September 2005. 
the conclusion that the form of EU rule making is exceptional. On the contrary, if the reading here is correct, the emergence of experimentalist governance in the EU and the potential for democratising destabilisation that goes with it foreshadow a possible future of the WTO and indeed governance on the global scale.

First submitted: April 2007 Final draft accepted: December 2007 